\title{
Climate Change, Coral Reef Ecosystems, and Management Options for Marine Protected Areas
}

\author{
Brian D. Keller · Daniel F. Gleason · Elizabeth McLeod · Christa M. Woodley • \\ Satie Airamé · Billy D. Causey · Alan M. Friedlander · Rikki Grober-Dunsmore • \\ Johanna E. Johnson · Steven L. Miller · Robert S. Steneck
}

Received: 2 June 2008/ Accepted: 28 June 2009/Published online: 28 July 2009

(c) The Author(s) 2009. This article is published with open access at Springerlink.com

\begin{abstract}
Marine protected areas (MPAs) provide placebased management of marine ecosystems through various degrees and types of protective actions. Habitats such as coral reefs are especially susceptible to degradation resulting from climate change, as evidenced by mass bleaching events over the past two decades. Marine ecosystems are being altered by direct effects of climate change including ocean warming, ocean acidification, rising sea level, changing circulation patterns, increasing severity of storms, and changing freshwater influxes. As impacts of climate change strengthen they may exacerbate effects of existing
\end{abstract}

\section{B. D. Keller $(\bowtie)$}

Southeast Atlantic, Gulf of Mexico, and Caribbean

Region, NOAA Office of National Marine Sanctuaries,

St. Petersburg, FL 33701, USA

e-mail: brian.keller@noaa.gov

\section{F. Gleason}

Biology Department, Georgia Southern University,

Statesboro, GA 30460, USA

\section{E. McLeod}

Asia Pacific Region, The Nature Conservancy, Honolulu, HI 96817, USA

\section{M. Woodley}

Center for Watershed Sciences, University of California, Davis, CA 95616, USA

\section{S. Airamé}

Partnership for Interdisciplinary Studies of Coastal Oceans, Marine Science Institute, University of California, Santa

Barbara, CA 93106, USA

\section{B. D. Causey}

Southeast Atlantic, Gulf of Mexico, and Caribbean Region, NOAA Office of National Marine Sanctuaries, Key West, FL 33040, USA stressors and require new or modified management approaches; MPA networks are generally accepted as an improvement over individual MPAs to address multiple threats to the marine environment. While MPA networks are considered a potentially effective management approach for conserving marine biodiversity, they should be established in conjunction with other management strategies, such as fisheries regulations and reductions of nutrients and other forms of land-based pollution. Information about interactions between climate change and more "traditional" stressors is limited. MPA managers are faced with high 
levels of uncertainty about likely outcomes of management actions because climate change impacts have strong interactions with existing stressors, such as land-based sources of pollution, overfishing and destructive fishing practices, invasive species, and diseases. Management options include ameliorating existing stressors, protecting potentially resilient areas, developing networks of MPAs, and integrating climate change into MPA planning, management, and evaluation.

Keywords Marine protected areas - Management options · Climate change $\cdot$ Coral reef ecosystems

\section{Introduction}

Human impacts have degraded marine ecosystems primarily through overexploitation and destructive fishing practices, pollution, and climate change. Overfishing and pollution have long histories (Jackson and others 2001; Lotze and others 2006; Roberts 2007), and presumably lower the resistance and resilience of marine ecosystems to further impacts from climate change. Comprehensive recommendations have been made for improving ocean policy in light of these threats (POC 2003; USCOP 2004) and for mitigating impacts of climate change (IPCC 2007c). At the same time, there is a pressing need to provide resource managers with approaches that can help maintain the structure and function of marine ecosystems in the face of climate change impacts.

There is growing recognition among scientists and marine resource managers that ecosystem-based approaches may help sustain the wide array of services provided by marine ecosystems (Rosenberg and McLeod 2005; Levin and Lubchenco 2008; Palumbi and others 2008; Ruckelshaus and others 2008). Marine protected areas (MPAs), particularly no-take marine reserves, can help restore ecosystem structure and function (Palumbi 2002; Sobel and Dahlgren 2004; Mumby and others 2006), and help protect marine biodiversity and associated ecosystem services (Ballantine 1997; NRC 2001; Palumbi 2002, 2004; Roberts and others 2003a; Sobel and Dahlgren 2004; Roberts 2005; Salm and others 2006; Palumbi and others 2009).

MPA networks are generally accepted as an improvement over individual MPAs to address multiple threats to

\section{S. L. Miller}

Center for Marine Science Research, University of North Carolina at Wilmington, Key Largo, FL 33037, USA

\section{R. S. Steneck}

Darling Marine Center, University of Maine, Walpole, ME 04573, USA the marine environment (Ballantine 1997; Salm and others 2000; Allison and others 2003; Roberts and others 2003b; Mora and others 2006; McLeod and others 2008b). Networks are more effective than single MPAs because networks spread the risk of reduced viability of a habitat or community type following a large-scale disturbance. Appropriately designed networks are better able to protect both short- and long-distance dispersers than individual MPAs and thus have greater potential to achieve conservation and fishery objectives (Roberts 1997). Networks can utilize local and regional dispersal patterns to enhance larval recruitment, be designed to protect critical life stages, and can protect critical ecological processes and functions such as migration corridors (Gerber and Heppell 2004). Finally, networks allow for protection of marine ecosystems at an appropriate scale; a network of MPAs can encompass a wide range of biogeographic and oceanographic conditions as an alternative to one extremely large area (NRC 2001; Hansen and others 2003).

While MPA networks are considered a critical management tool for conserving marine biodiversity, they must be established in conjunction with other management strategies to be effective (Hughes and others 2003; McLeod and others 2008b). MPAs are vulnerable to activities beyond their boundaries. For example, uncontrolled pollution and unsustainable fishing outside protected areas can adversely affect species and ecosystem functions within protected areas (Kaiser 2005). Therefore, MPA networks should be established considering other forms of resource management (e.g., fishery catch limits and gear restrictions) (Allison and others 1998; Beger and others 2003; Kaiser 2005) and integrated ocean and coastal management to control land-based threats such as pollution and sedimentation (Cho 2005). In the long term, the most effective configuration may be networks of highly protected areas nested within a broader management framework (Salm and others 2006). Such a framework might include an extensive multiple-use area integrated with coastal management regimes that help minimize land-based sources of pollution (e.g., Done and Reichelt 1998; McLeod and others 2008b).

This article is adapted from a preliminary review of management options (termed adaptations) for MPAs in the context of climate change (Keller and others 2008). We briefly discuss climate change stressors on marine ecosystems and interactions of these stressors with "traditional" ones, and then discuss options for MPA management in the context of climate change. We highlight coral reef ecosystems because it was beyond the scope of this review to comprehensively cover all types of marine ecosystems and because severe impacts on coral reefs such as mass bleaching events have been evident for decades and have been a topic of considerable research (e.g., Hoegh-Guldberg and others 2007a; Baker and others 2008). 


\section{Climate Change Stressors}

\section{Ocean Warming}

An average warming of $0.1^{\circ} \mathrm{C}$ has occurred in the $0-700 \mathrm{~m}$ depth layer of the ocean between 1961 and 2003 (Bindoff and others 2007). Increasing ocean temperatures affect a range of organismal physiological processes (Table 1) and influence ecological processes such as foraging, growth, and larval duration and dispersal, with ultimate impacts on the geographic ranges of species (Table 1). Within marine communities, these temperature changes and range shifts may result in new species assemblages and biological interactions (Table 1).

The IPCC $(2007 \mathrm{a}, \mathrm{b})$ reported that temperature increases over the last 50 years are nearly twice those for the last 100 years, with projections that global average surface air temperature will rise $1.8-4.0^{\circ} \mathrm{C}$ (lowest to highest scenarios) by 2090-2099, largely caused by increasing atmospheric carbon dioxide concentrations. Over the last 20 years, an extensive body of literature has conclusively linked anomalously high surface seawater temperatures as the major cause of coral bleaching (Table 1). Increases in sea surface temperature of about $1-3^{\circ} \mathrm{C}$ are likely to cause more frequent and severe mass coral reef bleaching events (Table 1) and will continue to cause widespread mortality unless thermal adaptation or acclimatization by corals occurs (IPCC 2007a). However, the ability of corals to adapt or acclimatize to increasing sea temperature is largely unknown (Berkelmans and van Oppen 2006) and remains a research topic of paramount importance. In 2005, the most devastating Caribbean-wide coral bleaching event to date occurred that based on modeling, was highly unlikely to have occurred without anthropogenic forcing (Donner and others 2007).

\section{Ocean Acidification}

The ocean absorbs about one-third of the carbon dioxide added to the atmosphere by human activities each year (Sabine and others 2004); and the $\mathrm{pH}$ of ocean surface waters has decreased by about 0.1 units since the beginning of the industrial revolution (Feely and others 2004). A doubling of the concentration of atmospheric carbon dioxide, which could occur in as little as 50 years, could cause major changes in the marine environment, specifically impacting organisms that build skeletal material out of calcium carbonate (Table 1). Because of the greater solubility of $\mathrm{CO}_{2}$ in cooler waters, reefs at the latitudinal margins of coral reef development (e.g., Florida Keys and Hawaiian Islands) may show the most rapid and dramatic response to changing $\mathrm{pH}$. On the other hand, McNeil and others (2004) suggested that net coral reef calcification rates will increase with future ocean warming and exceed pre-industrial rates by the year 2100 .

Although additional research is needed to resolve this issue, increasing seawater acidification has been shown in controlled studies to significantly reduce the ability of reefbuilding corals to produce their skeletons, affecting growth of individual corals and making reefs more vulnerable to erosion (Langdon and Atkinson 2005; Yates and Halley 2006). Some estimates indicate that at atmospheric $\mathrm{CO}_{2}$ levels close to 2-3 times the pre-industrial levels coral reefs may erode faster than they can be rebuilt potentially making them less resilient to other environmental stresses (e.g., disease, bleaching, storms) (Hoegh-Guldberg and others 2007a). This could compromise the long-term viability of these ecosystems, perhaps impacting the thousands of species that depend on reef habitats (McLeod and others 2008b).

\section{Sea Level Rise}

During the last 100 years, global average sea level has risen an estimated 1-2 $\mathrm{mm}$ per year and is expected to accelerate due to thermal expansion of the oceans and melting ice-sheets and glaciers (Cabanes and others 2001; Albritton and Filho 2001; Rignot and Kanagaratnam 2006; Chen and others 2006; Shepherd and Wingham 2007; Bell and others 2007; IPCC 2007a). Rates of sea level rise at a local scale vary from -2 to $10 \mathrm{~mm}$ per year along U.S. coastlines (Nicholls and Leatherman 1996; Zervas 2001; Scavia and others 2002). The consequences of sea level rise include inundation of coastal areas, erosion of vulnerable shorelines, landward shifts in species distributions, and saltwater intrusion into estuaries and aquifers (Klein and Nicholls 1999) (Table 1). However, coastal development may interfere with landward plant migrations and cause submergence of wetlands and waterlogged soils, which in turn result in plant physiological stress or die-off. Depletion or loss of marshes, mangroves, and dune plants would affect nutrient flux, energy flow, and essential habitat for a multitude of species (Table 1).

\section{Variability in Ocean-Atmosphere Interactions} and Ocean Circulation

Natural climatic variability resulting from ocean-atmosphere interactions such as the El Niño-Southern Oscillation (ENSO), Pacific Decadal Oscillation (PDO), and North Atlantic Oscillation/Northern Hemisphere Annular Mode result in changes in open ocean productivity, shifts in the distribution of organisms, and modifications in food webs that foreshadow potential consequences of accelerated climate change (e.g., Mantua and others 1997; McGowan and others 1998). These recurring patterns of ocean-atmosphere 


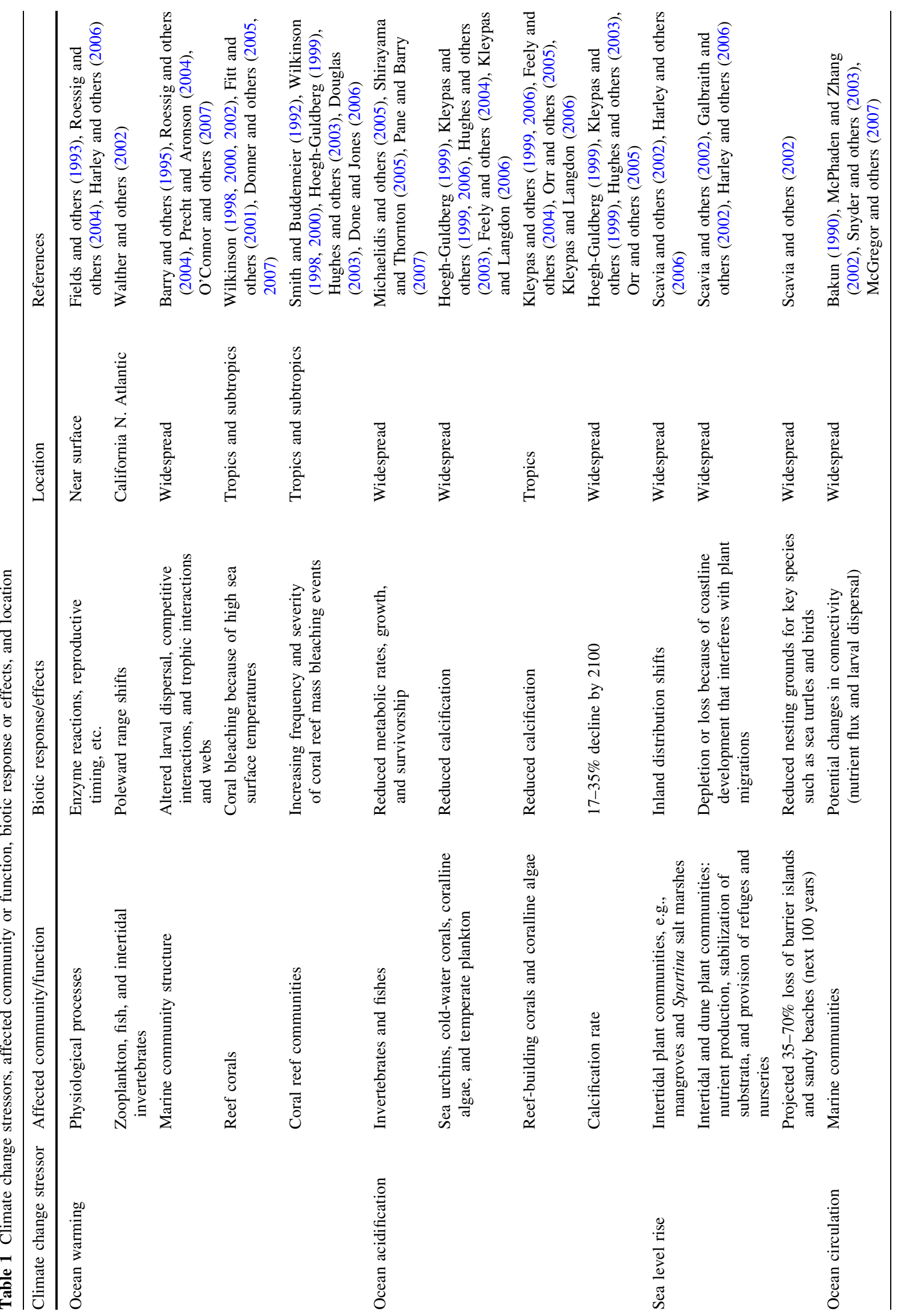




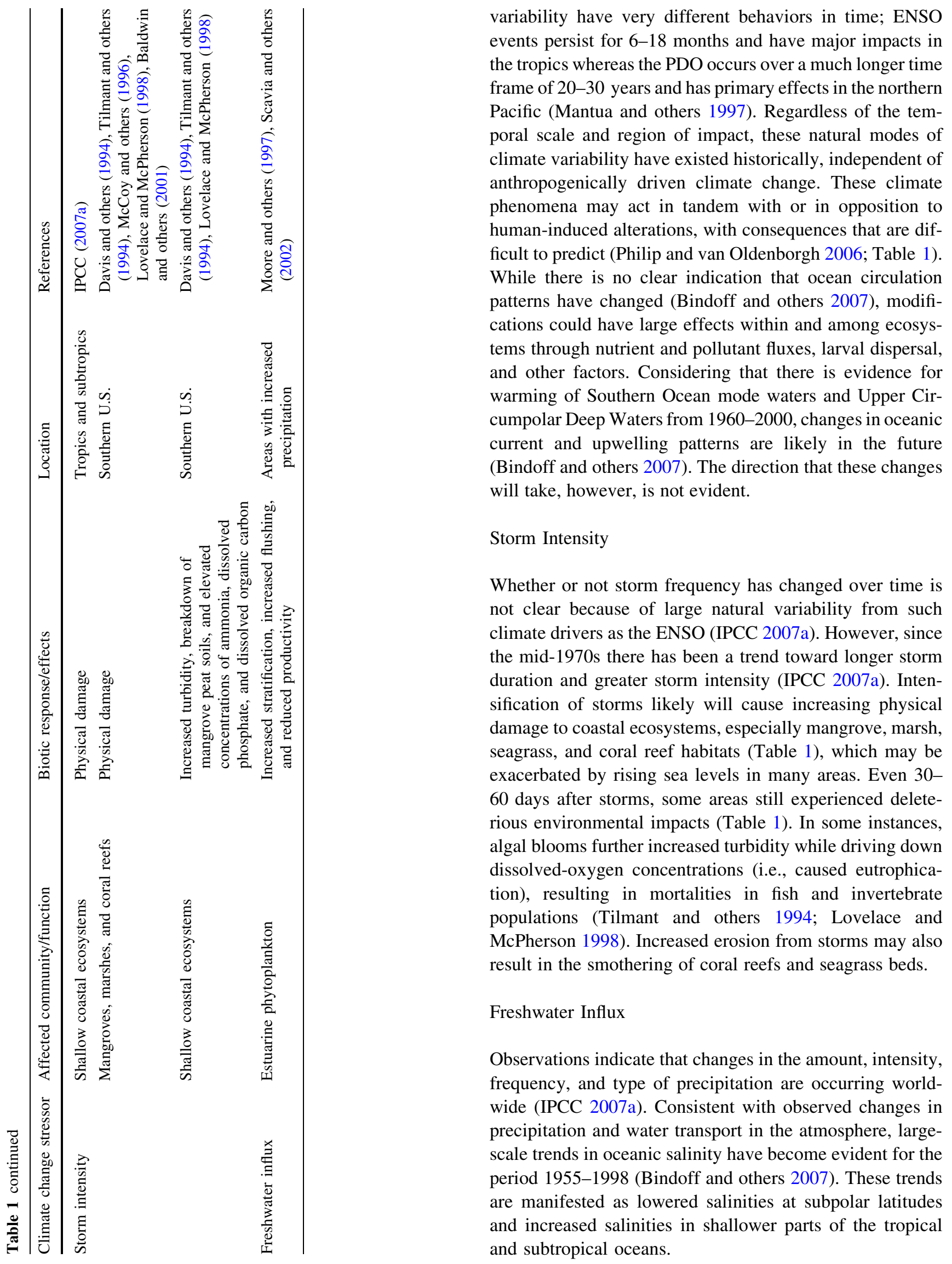


In addition to altering salinity in major oceanic water masses, changes in precipitation patterns can have significant impacts in estuarine and other nearshore environments. For instance, in regions where climate change results in elevated rainfall, increased runoff may cause greater stratification of water layers within estuaries, less water column mixing and thus lower rates of nutrient exchange among water layers, and significantly reduced productivity because phytoplankton populations may be flushed from the system faster than they can grow and reproduce (Table 1). On the other hand, estuaries that are located in regions with lower rainfall may also show decreased productivity because of lower nutrient influx. Thus, the relationship between precipitation and marine ecosystem health is complex and difficult to predict.

Another source of fresh water is melting of polar ice (IPCC 2007a). In the Atlantic Ocean, accelerated melting of Arctic ice and the Greenland ice sheet are predicted to continue producing more freshwater inputs that may alter oceanic circulation patterns (Dickson and others 2002; Curry and others 2003; Curry and Mauritzen 2005; Peterson and others 2006; Greene and Pershing 2007; Boessenkool and others 2007).

\section{Climate Change Interactions with "Traditional" Stressors of Concern}

\section{Land-Based Sources of Pollution}

Marine water-quality degradation and pollution stem primarily from land-based sources, with major contributions to coastal watersheds and water-quality deterioration falling into two broad categories: point-source pollution and non-point-source pollution. Point-source pollution from factories, sewage treatment plants, and farms often flows into nearby waters. In contrast, marine non-point-source pollution originates from coastal urban runoff where the bulk of the land is paved or covered with buildings. These impervious surfaces prevent soils from capturing runoff, resulting in the input of untreated pollutants (e.g., fuels, oils, plastics, metals, insecticides, antibiotics) to coastal waters. Increased terrestrial runoff due to more intense storm events associated with climate change may increase land-based water pollution from both of these sources. In some areas, increased groundwater outflows may also contribute to coastal pollution.

Deterioration and pollution of coastal watersheds can have far-reaching effects on marine ecosystems, for example, the Gulf of Mexico "dead zone" that occurs each summer (Table 2). This mass of hypoxic water has its origins in the increased nitrate flux coincident with the exponential growth of fertilizer use that has occurred since the 1950s in the Mississippi River basin. Pollution has been one of the major drivers of decreases in the health of marine ecosystems such as coral reefs and seagrass and kelp beds (Table 2). Because pollution has usually been more local in scope, adopting integrated ocean and coastal management has enabled MPA and watershed managers to work cooperatively toward managing pollution (Cicin-Sain and Belfiore 2005).

The addition of climate change stressors such as increased oceanic temperature, decreased $\mathrm{pH}$, and greater fluctuations in freshwater influxes and salinity may exacerbate potentially deleterious effects of pollution (Coe and Rogers 1997; Carpenter and others 1998; Khamer and others 2000; Burton and Pitt 2001; Sobel and Dahlgren 2004; Orr and others 2005; Breitburg and Riedel 2005; O'Connor and others 2007; IPCC 2007a). In regions where climate change causes precipitation and freshwater influxes to increase, the scale of water quality degradation may expand. Coral bleaching from the combined stresses of climate change and local pollution (e.g., high temperature and sedimentation) has already been observed (Jackson and others 2001; Hughes and others 2003; Pandolfi and others 2003). Identifying those stressors with the greatest effect is not trivial, and research in coral genomics may provide diagnostic tools for identifying stressors in coral reefs and other marine communities (e.g., Edge and others 2005, 2008).

\section{Overfishing and Destructive Fishing Practices}

Commercial fishing has ecosystem effects on three fronts: overfishing, often of multiple fishery species; physical impacts on habitats caused by fishing gear such as trawls, seines, and dredges and fishing practices that use dynamite or cyanide; and incidental take of non-targeted species (bycatch) (Table 2). Fishery populations that are overstressed and overfished exhibit greater sensitivity to climate change and other anthropogenically derived stressors than healthy populations (Hughes and others 2005). Overfishing can reduce mean life span as well as lifetime reproductive success and larval quality, making fished species more susceptible to both short- and long-term perturbations (such as changes in prevailing current patterns) that affect recruitment success (Pauly and others 1998, 2003; Jackson and others 2001; Dayton and others 2002; Sobel and Dahlgren 2004; Estes 2005; Law and Stokes 2005; Steneck and Sala 2005; O'Connor and others 2007). Changing climatic regimes can also influence species' distributions, which are set in part by physiological tolerances to temperature, dissolved oxygen, $\mathrm{pH}$, and salinity. Because rates of climate change appear to exceed the capacity of many commercially fished species to adapt to changing local conditions, species may shift their ranges in accordance with physiological thresholds and may ultimately be forced 


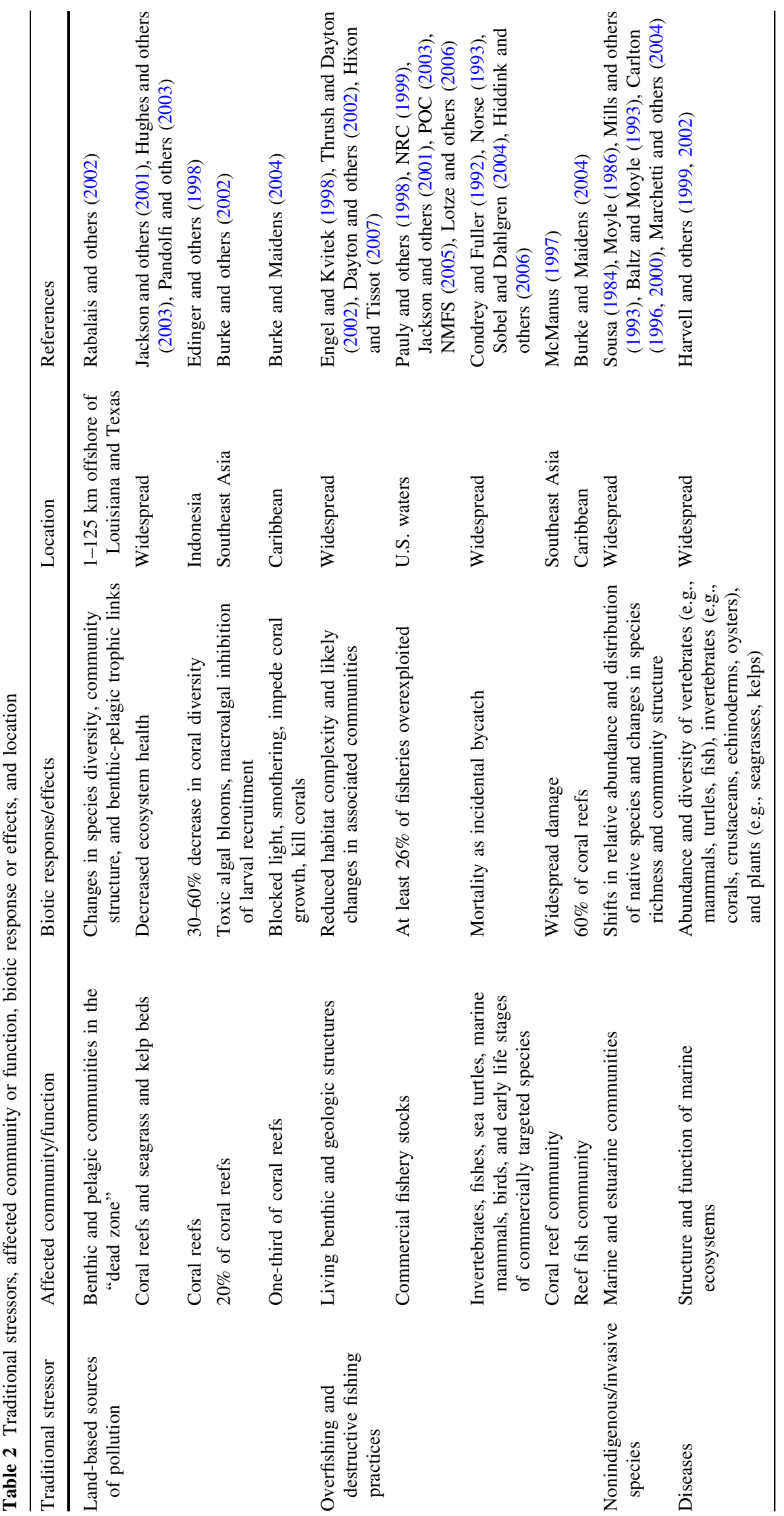


to extend past the boundaries of their "known" native ranges, becoming seemingly invasive elements (Murawski 1993; Walther and others 2002; Roessig and others 2004; Perry and others 2005; Harley and others 2006).

Commercial exploitation of even a single keystone species, such as a top consumer, can destabilize ecosystems by decreasing redundancy and making them more susceptible to climate change stressors (Hughes and others 2005). Examples of such ecosystem destabilization through overfishing abound, including the formerly cod-dominated system of the western North Atlantic (Steneck 1997; Steneck and others 2004), and the fish grazing community on Caribbean coral reefs (e.g., Frank and others 2005; Mumby and others 2006, 2007).

Interestingly, the theoretical framework that links no-take marine reserves with improved coral condition has been a matter of some debate (e.g., Jackson and others 2001; Grigg and others 2005; Pandolfi and others 2005; Aronson and Precht 2006; Jackson 2008). This stems from the nature of cascading effects triggered by reserves, which may involve increases in herbivorous reef fishes in areas where they are fished; increased herbivory reduces macroalgae that can overgrow corals and inhibit coral recruitment. However, reserves also protect predators, so declines in herbivorous fish might occur unless there is an escape in size from predation and the rate of herbivory actually increases (Mumby and others 2006). Data from field studies provide conflicting results. Mumby and others (2006) showed that increased densities of large herbivorous fish in a marine reserve reduced algal growth after mass bleaching caused extensive coral mortality, but such increases in herbivore densities do not always occur after protection is provided (Mosquera and others 2000; Graham and others 2003; Micheli and others 2004; Robertson and others 2005). Further, Burkepile and Hay (2008) have documented important differences in grazing behavior among three Caribbean parrotfishes, highlighting the importance of herbivore community structure to grazing effects. Finally, there is widespread belief that the 1983-1984 mass mortality of Diadema antillaruma major grazing sea urchin on Caribbean reefs-was a significant proximal cause of coral reef decline throughout the Caribbean. However, as reported in Aronson and Precht (2006) half the decline in live coral cover throughout the Caribbean reported by Gardner and others (2003) occurred before this die-off, and immediately after the die-off coral cover remained unchanged. Subsequent declines in cover were associated with mass coral bleaching events (1987, 1997-1998) and possibly with continued losses to diseases. It is important to highlight this complexity because it emphasizes how much is unknown about basic ecological processes on coral reefs and consequently how much needs to be learned about whether no-take marine reserves work effectively to enhance ecosystem resilience when disease and bleaching remain significant sources of coral mortality (Aronson and Precht 2006; Bruno and Selig 2007).

\section{Nonindigenous/Invasive Species}

Invasive species threaten all marine and estuarine communities (Table 2). Currently, an estimated $2 \%$ of extinctions in marine ecosystems are related to invasive species while $6 \%$ are the result of other factors including climate change, pollution, and disease (Dulvy and others 2003). Principal mechanisms of introduction vary and include both accidental and intentional release (Ruiz and others 2000; Carlton 2000; Hare and Whitfield 2003).

Some native species, particularly rare and endangered ones with small population sizes and gene pools, are unlikely to be able to adapt quickly enough or shift their ranges rapidly enough to compensate for the changing climatic regimes proposed by current climate change models (IPCC 2007a). These native species will likely have their competitive abilities compromised and be more susceptible to displacement by invasive species, and therefore should be considered for stronger protective measures by MPA managers. Increased seawater temperatures resulting from climate change may also enable introduced species to spawn earlier and for longer periods, thus increasing their population growth rates relative to natives while simultaneously expanding their range (Carlton 2000; McCarty 2001; Stachowicz and others 2002; Marchetti and others 2004). Furthermore, the same characteristics that make species successful invaders may also make them pre-adapted to respond to, and capitalize on, climate change. As one example, Indo-Pacific lionfish (Pterois volitans and $P$. miles) are now widely distributed and abundant off the southeastern coast of the United States and in the Bahamas less than 10 years after being first observed off Florida (Whitfield and others 2007; Snyder and Burgess 2007; Freshwater and others 2009). One of the few factors limiting their spread is intolerance to minimum water temperatures during winter (Kimball and others 2004); ocean warming could facilitate depth and range expansion in these species.

\section{Diseases}

Pathogen outbreaks or epizootics spread rapidly due to the lack of dispersal barriers in some parts of the ocean and the potential for long-term survival of pathogens outside the host (Table 2). Many pathogens of marine taxa such as coral viruses, bacteria, and fungi respond positively to temperature increases within their physiological thresholds (Porter and others 2001; Kim and Harvell 2004; Munn 2006; Mydlarz and others 2006; Boyett and others 2007). However, it is noteworthy that white-band disease was the primary cause (though not the only cause) of reduced coral cover on 
Caribbean reefs from the late 1970s through the early 1990s (Aronson and Precht 2006). That outbreak did not correspond to a period of particularly elevated temperature [R. Aronson, personal communication; but see Lesser and others (2007)].

Exposure to disease compromises the ability of species to resist other anthropogenic stressors and vice versa (Harvell and others 1999, 2002). For example, in 1998, the most geographically extensive and severe coral bleaching ever recorded was associated with the high anomalies in sea surface temperatures associated with an ENSO event (Hoegh-Guldberg 1999; Wilkinson and others 1999; Mydlarz and others 2006). In some species of reef-building corals and gorgonians, this bleaching event was thought to be accelerated by opportunistic infections (Harvell and others 1999, 2001). Several pathogens-such as bacteria, viruses, and fungi that infect such diverse hosts as seals, abalone, and starfish-show possible onset with warmer temperatures (reviewed in Harvell and others 2002) and some coral species may become more susceptible to disease after bleaching events (Whelan and others 2007). The mechanisms for pathogenesis, however, are largely unknown. Given that exposure to multiple stressors may compromise the ability of marine species to resist infection, the most effective means of reducing disease incidence under climate change may be to minimize impacts of stressors such as pollution and overfishing.

\section{Options for Marine Protected Area Management in the Context of Climate Change}

Options for management of MPAs in response to climate change can be organized at two levels: actions at existing sites and establishment of new sites, particularly if they are arranged as networks (Table 3). Within MPAs, managers can increase efforts to ameliorate existing anthropogenic stressors with a goal of reducing the overall load of multiple stressors (Breitburg and Riedel 2005). For example, the concept of protecting or enhancing coral reef resilience has been proposed to help ameliorate negative consequences of coral bleaching (Hughes and others 2003, 2005; West and Salm 2003; Marshall and Schuttenberg 2006a; Salm and others 2006). Under this approach, resilience is an ecosystem property that can be managed, and is defined as the ability of an ecosystem to resist or absorb disturbance while maintaining key functions and processes (Gunderson 2000; Nyström and others 2000; Hughes and others 2003; McLeod and others 2008b). Managing for resilience includes addressing causes of disturbance and decline at a local scale such as overfishing and pollution, identifying and protecting potentially resilient areas, and designing networks of MPAs to address threats at broader scales. Networks of MPAs should be designed to take advantage of properties of systems of sites. These properties include connectivity, protection of ecologically critical areas, and replication and representation of multiple habitat types (Salm and others 2006; McLeod and others 2008b).

It is important to emphasize that variable and complex effects of climate on oceanographic processes and production (Soto 2002; Mann and Lazier, 2006) present MPA managers with major uncertainties about climate change impacts and effective management approaches. Nevertheless, it is imperative to integrate climate change into MPA management plans using the best available scientific information.

Table 3 Management options for MPA managers in the context of climate change (see McLeod and others 2008b)

\footnotetext{
$\checkmark$ Manage human stressors such as fishing and inputs of nutrients, sediments, and pollutants within MPAs.

$\checkmark$ Improve water quality by raising awareness of adverse effects of land-based activities on marine environments, implementing integrated coastal and watershed management, and developing options for advanced wastewater treatment.

$\checkmark$ Manage functional species groups necessary to maintaining the health of reefs and other ecosystems.

$\checkmark$ Identify and protect areas that appear to be resistant to climate change effects or to recover from climate-induced disturbances.

$\checkmark$ Identify and protect ecologically significant ("critical”) areas such as nursery grounds, spawning grounds, and areas of high species diversity.

$\checkmark$ Identify ecological connections among ecosystems and use them to inform the design of MPAs and management decisions such as protecting resistant areas to ensure sources of recruitment for recovery of populations in damaged areas.

$\checkmark$ Design MPAs with dynamic boundaries and buffers to protect breeding and foraging habits of highly migratory and pelagic species.

$\checkmark$ Establish dynamic MPAs defined by large-scale oceanographic features such as oceanic fronts where changes in types and abundances of organisms often occur.

$\checkmark$ Maximize habitat heterogeneity within MPAs and consider protecting larger areas to preserve biodiversity, ecological connections among habitats, and ecological functions.

$\checkmark$ Include entire ecological units (e.g., coral reefs with their associated mangroves and seagrasses) in MPA design to help maintain ecosystem function and resilience.

$\checkmark$ Ensure that the full breadth of habitat types is protected (e.g., fringing reef, fore reef, back reef, patch reef).

$\checkmark$ Replicate habitat types in multiple areas to spread risks associated with climate change.
} 
Ameliorate Existing “Traditional” Stressors

Managers may be able to increase resilience to climate change within MPAs by reducing impacts of local- and regional-scale stressors, such as fishing, input of nutrients, sedimentation and pollutants, and degraded water quality. While this concept is logical and has considerable appeal, evidence in support of this approach is limited. Behrens and Lafferty (2004) found that kelp forest ecosystems in no-take marine reserves were more resilient to ocean warming than in reference areas as a result of changes in trophic structure of communities in and around reserves. In reference areas where predators such as spiny lobster were fished, herbivorous sea urchin prey increased in abundance and consumed giant kelp and other algae. In reserves where fishing was prohibited, lobster populations were larger, urchin populations were diminished, and kelp forests persisted over a period of 20 years, including four ENSO cycles (Behrens and Lafferty 2004). Although MPAs have been shown to be effective at mitigating stresses at local scales, they may be less effective at addressing global climate change threats such as mass bleaching events (see Bruno and Selig 2007) unless they are designed specifically to address resilience.

Managing water quality has been identified as a key strategy for maintaining ecological resilience (Salm and others 2006; Marshall and Schuttenberg 2006a). In the Florida Keys National Marine Sanctuary and the Great Barrier Reef Marine Park water quality protection is recognized as an essential component of management (USDOC 1996; Grigg and others 2005). Strong circumstantial evidence links poor water quality to increased macroalgal abundances, increased bioerosion, and higher susceptibility to some diseases in corals and octocorals (Fabricius and De'ath 2004). Addressing sources of pollution, especially nutrient enrichment that can lead to increased algal growth and reduced coral settlement, is critical to ecosystem structure and function. In addition to limiting point-source pollution within an MPA, sources from beyond MPA boundaries should be controlled as much as possible through collaborations with appropriate authorities in adjacent areas (see Crowder and others 2006). For example, MPA managers should work with land and watershed managers to develop and implement strategies to reduce land-based pollution, decrease nutrient and sediment runoff, eliminate the use of persistent pesticides, and increase filtration of effluent through wetlands to improve quality of coastal waters. Actions such as these should be coupled with research to investigate their efficacy.

Another mechanism that may help maintain resilience of coral reef ecosystems is the management of functional groups, specifically herbivores (Hughes and others 2003; Bellwood and others 2004; McLeod and others 2008b). Bellwood and others (2004) identified three functional groups of herbivores that assist in maintaining coral reef resilience: bioeroders, grazers, and scrapers. These groups work together to break down dead coral to allow substrate for recruitment, graze macroalgae, and reduce the development of algal turfs to provide substrata suitable for coral settlement. Attention must also be paid to the roles of individual species within these groups (Burkepile and Hay 2008). Bellwood and others (2006) identified the need to protect both the species that prevent phase shifts from coralto algal-dominated reefs and species that help reefs recover from algal dominance. While parrotfishes and surgeonfishes appear to play a critical role in preventing phase shifts to macroalgae [but see Ledlie and others (2007)], they may have limited ability to reverse such a shift. In one study, phase-shift reversal from macroalgal- to a coral- and epilithic algal-dominated state surprisingly was caused by a single batfish species (Platax pinnatus) rather than parrotfishes and other herbivores (Bellwood and others 2006).

Although protecting functional groups may be a component of MPA management to enhance resilience, understanding which groups should be protected requires a detailed knowledge of species and interactions that is not often available. Coral reefs appear to require key herbivores in sufficient numbers to reduce macroalgae and enhance coral settlement, whereas kelp forests may require key predators on herbivores to reduce herbivory and promote kelp recruitment and growth. Manipulating functional groups should be field tested at different locations to verify their appropriateness. As a precaution, managers should strive to maintain the maximum number of species, particularly in the absence of detailed ecological data.

\section{Protect Potentially Resilient Areas}

Marine ecosystems face potential loss of habitat structure as climate change progresses (e.g., coral reefs, seagrass beds, kelp forests, and deep coral communities) (see HoeghGuldberg 1999; Steneck and others 2002; Roberts and others 2006; Orth and others 2006). It is likely that climate change contributes to mass coral bleaching events (Reaser and others 2000), which became global in 1998 (Wilkinson 1998, 2000) and have affected large regions in subsequent years (Wilkinson 2002, 2004; Whelan and others 2007). The amount of live coral has declined dramatically in the Caribbean region over the past 30 years as a result of bleaching, diseases, and hurricanes (Gardner and others 2003, 2005). In the Florida Keys, some fore-reef environments that formerly supported dense growths of coral are now depauperate, and highest coral cover is in patch reef environments (Porter and others 2002; Lirman and Fong 2007). Irrespective of the mechanism-resistance, resilience, or exposure to relatively low levels of past environmental stress-these patch reefs are good candidates for 
additional protective measures because they may have high potential to survive climate stress.

Done (2001; see also Marshall and Schuttenberg 2006b) presented a decision tree for identifying areas that would be suitable for MPAs under a global warming scenario. Two types of favorable outcomes included reefs that survived bleaching (i.e., were resilient) and reefs that were not exposed to elevated sea surface temperatures (e.g., may be located within refugia such as areas exposed to upwelling or cooler currents). This type of decision tree has already been adapted to guide site selection for mangroves (McLeod and Salm 2006), and could be extended further for other habitat types such as seagrass beds and kelp forests.

In addition, thermally stressed corals may exhibit less bleaching and higher survival if they are shaded during periods of elevated temperatures (West and Salm 2003; Hoegh-Guldberg and others 2007b). On a small scale, MPA managers may be able to select sites that are naturally shaded by high islands, emergent rocks or corals overhead. For example, in the Rock Islands of Palau, corals in more shaded parts of the reef survived a bleaching event better than those in more exposed parts of the reef (West and Salm, 2003). MPA managers may also consider shading areas during bleaching events to reduce UV radiation impacts and overall stress (Hoegh-Guldberg and others 2007b). On a larger scale, managers should protect mangrove shorelines and support restoration of areas where mangroves have been damaged or destroyed because tannins and dissolved organic compounds from decaying mangrove vegetation contribute to absorbing light and reducing stress on adjacent coral reefs (Hallock 2005). Extensive discussions of coral bleaching and management responses are provided in Marshall and Schuttenberg (2006a, b), Johnson and Marshall (2007), and McLeod and others (2008b).

\section{Develop MPA Networks}

The concept of networks of MPAs has gained appeal for a number of reasons, and network design to address impacts of climate change was recently reviewed by McLeod and others (2008b). Emergent properties of systems such as representation, replication, and connectivity (Ballantine 1997; NRC 2001; Roberts and others 2003a; West and Salm 2003; Salm and others 2006; McLeod and others 2008b) are attractive to MPA managers who have realized that relatively small, isolated protected areas may not adequately protect ecosystem structure and function. Also, networks likely lower the risk of catastrophic habitat loss (Palumbi 2002; Allison and others 2003), which may provide a form of "insurance" for management of biogenically structured, slow-growing habitats such as coral reefs. Finally, networks may provide functional wilderness areas sufficiently extensive to resist fundamental changes to ecosystems (Kaufman and others
2004). While MPA networks have been recognized as a valuable tool to conserve marine resources in the face of climate change, there have been a number of challenges to their implementation (Pandolfi and others 2005; Mora and others 2006). A set of recommendations has been developed to aid MPA network design and implementation, which include MPA size and spacing, risk spreading, protection of critical areas, connectivity, ecosystem function, and ecosystem-based management (McLeod and others 2008b).

Guidelines for the minimum size of MPAs and no-take marine reserves, and spacing between adjacent MPAs, vary depending on their goals (Hastings and Botsford 2003). For example, Friedlander and others (2003) suggested that notake zones should measure ca. $10 \mathrm{~km}^{2}$ to ensure viable populations of a range of species in the Seaflower Biosphere Reserve, Colombia. Palumbi (2003) concluded that marine reserves tens of $\mathrm{km}$ apart may exchange larvae in a single generation. Shanks and others (2003) similarly concluded that marine reserves spaced $20 \mathrm{~km}$ apart would allow larvae to be carried to adjacent reserves. The Science Advisory Team to California's Marine Life Protection Act Initiative recommended spacing highly protected MPAs, such as marine reserves, within $50-100 \mathrm{~km}$ in order to accommodate larval dispersal distances of a wide range of species of interest. Halpern and others (2006) corroborated these findings using an uncertainty-modeling approach.

It has been suggested that no-take zones measuring a minimum of $20 \mathrm{~km}$ in diameter may accommodate shortdistance dispersers in addition to including a significant portion of local benthic fish populations, thus generating fisheries benefits (Shanks and others 2003; Fernandes and others 2005; Mora and others 2006; McLeod and others 2008b). A single network design is unlikely to satisfy the potential dispersal ranges for all species; Roberts and others (2003b) recommended an approach using various sizes and spacing of MPAs in a network to accommodate the diversity of dispersal ranges, which likely will be all the more necessary in the context of further variabilities caused by climate change. Recommendations to protect highly migratory and pelagic species include designing MPAs to protect predictable breeding and foraging habits, ensuring these have dynamic boundaries and extensive buffers, and establishing dynamic MPAs that are defined by the extent and location of large-scale oceanographic features such as oceanic fronts where changes in types and abundances of marine organisms often occur (Hyrenbach and others 2000).

Risk spreading to minimize the likelihood of loss of habitat types (Salm and others 2001; West and Salm 2003; McLeod and others 2008b) involves protection of multiple samples of each type (Hockey and Branch 1994; Ballantine 1997; Roberts and others 2001, 2003b; Friedlander and others 2003; Salm and others 2006; Wells 2006). Examples of marine habitat types include coral reefs with varying 
degrees of exposure to wave energy (e.g., offshore, midshelf, and inshore reefs) and a range of types of mangrove forests (riverine, basin, and fringe forests in areas of varying salinity, tidal fluctuation, and sea level) (Salm and others 2006).

There are several recommendations about proportions or numbers of habitat types to protect. For example, it has been recommended that more than $30 \%$ of appropriate habitats should be included in no-take marine reserves (Bohnsack 2000). In 2004, the Great Barrier Reef Marine Park Authority increased the area of no-take marine reserves from less than 5\% to approximately $33 \%$ of the area of the Marine Park, ensuring that at least $20 \%$ of each bioregion (area of every region of biodiversity) was zoned as no-take (Day and others 2002; Fernandes and others 2005). Also, Airamé and others (2003) recommended a network of three to five no-take zones in each biogeographic region of the Channel Islands National Marine Sanctuary, comprising approximately $30-50 \%$ of the area, in order to conserve biodiversity and contribute to sustainable fisheries in the region. An additional consideration is placement of reserves, which could be designed to minimize the risk of loss to catastrophic disturbances such as mass bleaching events in order to maximize achieving conservation targets (Game and others 2008).

Biologically or ecologically significant "critical areas" should be protected; critical areas include nursery habitats, spawning aggregations or areas, areas of high species diversity, heterogeneous habitat clusters, and areas that are not exposed to extremes of climate change (Allison and others 1998; Sale and others 2005; Sadovy 2006; McLeod and others 2008b). For example, areas of coral reefs that appear to be resilient to climate change should be provided with a high level of protection to help ensure a secure source of recruitment to damaged areas within an MPA network (Salm and Coles 2001). Responses to past bleaching events and other disturbances may provide insights into resilience; some coral colonies may have genetic characteristics that confer resistance to bleaching or may avoid bleaching because of environmental factors such as currents and shading that provide protection from temperature and/or irradiance anomalies. Highly protected critical areas should be as large as possible to maximize their effectiveness as sources of recruits (Palumbi and others 1997; Bellwood and Hughes 2001; Salm and others 2006).

Connectivity via larval dispersal and the movement of adults and juveniles has been investigated and reviewed extensively (e.g., Roberts 1997; Crowder and others 2000; Stewart and others 2003; Roberts and others 2003b; Cowen and others 2006; Salm and others 2006; Steneck 2006; McLeod and others 2008b). In addition to designing MPA networks for connectivity among different sites containing a particular habitat type, connectivity among habitat types such as mangroves, coral reefs, and seagrass beds (Ogden and Gladfelter 1983; Roberts 1996; Nagelkerken and others 2000; Mumby and others 2004; McLeod and others 2008b).

Although maintaining connectivity within and between MPAs may help maintain marine biodiversity, ecosystem function, and resilience, many challenges exist. For example, the same currents and pathways that enable larval recruitment can expose an ecosystem to invasive species, pathogens, parasites, and pollutants, which can undermine the resilience of a system (McClanahan and others 2002). Numerous challenges also exist in estimating larval dispersal patterns. Although there have been detailed studies addressing dispersal potential of marine species based on their larval biology (e.g., Shanks and others 2003; Kinlan and Gaines 2003), little is known about where in the oceans larvae go and how far they travel. Larval duration in the plankton also varies from minutes to years, and the more time propagules spend in the water column, the farther they tend to be dispersed (Shanks and others 2003; Steneck 2006). Evidence from hydrodynamic models and genetic structure data indicates that in addition to large variation of larval dispersal distances among species, the average scale of dispersal can vary widely-even within a given species-at different locations in space and time (e.g., Cowen and others 2003; Sotka and others 2004; Engie and Klinger 2007). Some information suggests long-distance dispersal is common, but other emerging information suggests that larval dispersal may be limited (Jones and others 1999, 2005; Swearer and others 1999; Warner and others 2000; Thorrold and others 2001; Palumbi 2003; Paris and Cowen 2004). Additional research will be required to better understand where and how far larvae travel in various marine ecosystems.

For both terrestrial and marine systems, species diversity often increases with habitat diversity, and species richness increases with habitat complexity; the greater the variety of habitats protected, the greater the biodiversity conserved (Friedlander and others 2003; Carr and others 2003). High species diversity may increase ecosystem resilience by ensuring sufficient redundancy to maintain ecological processes and protect against environmental disturbance (McNaughton 1977; McClanahan and others 2002). This is particularly the case in the context of additive or synergistic stressors. Maximizing habitat heterogeneity is critical for maintaining ecological health, thus MPAs should include large areas and depth gradients (Done 2001; Hansen and others 2003; Roberts and others 2003a). By protecting a representative range of habitat types and communities, MPAs have a higher potential to protect a region's biodiversity, biological connections between habitats, and ecological functions (Day and others 2002). 
Table 4 Integrate climate change into MPA planning, management, and evaluation: The Great Barrier Reef as an example

The Great Barrier Reef Marine Park Authority (GBRMPA) is exemplary with regard to the degree to which it has inawcorporated climate change into its management program. GBRMPA has implemented a comprehensive Climate Change Response Program (http://www.gbrmpa.gov.au/, accessed 23 May 2008) that establishes guidelines for other MPA managers to consider. A thorough assessment of vulnerabilities to climate change (Johnson and Marshall 2007) set the stage for management recommendations. "A Reef Manager's Guide to Coral Bleaching" (Marshall and Schuttenberg 2006a) provided information on the causes and consequences of coral bleaching and management strategies to help local and regional reef managers reduce this threat to coral reef ecosystems. GBRMPA has expanded its area of no-take management of human uses from a total proportion of less than 5 to $33 \%$, using a representative areas approach (Day and others 2002; Fernandes and others 2005). It remains to be seen whether this expansion of no-take zoning within the Great Barrier Reef Marine Park will influence susceptibility of coral reefs to mass bleaching events (see Bruno and Selig 2007).

\section{Integrate Responses to Impacts of Climate Change in MPA Management}

Scientists and managers involved with coral reef MPAs have collaborated on a guide about coral bleaching that provides a number of recommendations to MPA managers (Marshall and Schuttenberg 2006a). In contrast, impacts of ocean acidification (Caldeira and Wickett 2003) do not have clearly articulated management strategies, although efforts are currently being made to develop these strategies (McLeod and others 2008a). Further research is needed on impacts of high concentrations of $\mathrm{CO}_{2}$ in the oceans, possible acclimation or evolution of organisms in response to changes in ocean chemistry, and how management might respond (TRS 2005). Possible responses to other climate change stressors such as sea level rise, ocean circulation, storm intensity, and freshwater influx also require further research, and may not have management options as well explored and tested as those for traditional stressors such as pollution, commercial fishing, invasive species, and diseases.

Interactions of climate change stressors with traditional stressors compress the spatial extent of impacts and management responses from global and regional scales to more local manifestations.

Nevertheless, we suspect that many management plans for coral reef and other MPAs do not explicitly address actions or options in the context of climate change, and we hope that recommendations provided here and elsewhere (Table 4) will help fill this gap. Managers and scientists need to work together closely with stakeholders to consider regional scenarios of impacts of climate change and ecosystem responses, and determine how best to implement science-based management responses.

Acknowledgments We thank all the individuals who participated in the stakeholder workshop, 24-25 January 2007, and whose lively discussion provided information and comments that helped form the contents and conclusions of this article. We thank the anonymous reviewers and the following people for comments on the report from which this article was adapted: R. Aronson, J. Brown, P. Bunje, D. Burden, A. DeVogelaere, E. Druffel, W. Fisher, H. Galbraith, P. Hallock Muller, J. Lang, J. Martinich, J. Ogden, W. Wiltse, and J. Yang; we are grateful to S. Julius and J. West for their guidance, support, and suggestions for improvements of the report. E. McLeod and B. D. Keller acknowledge the major contributions of Rod Salm to the issue of climate change, coral reef resilience, and marine protected areas. Finally, we thank the reviewers of Environmental Management for their helpful and constructive comments, which greatly improved the article.

Open Access This article is distributed under the terms of the Creative Commons Attribution Noncommercial License which permits any noncommercial use, distribution, and reproduction in any medium, provided the original author(s) and source are credited.

\section{References}

Airamé S, Dugan JE, Lafferty KD, Leslie H, McArdle DA, Warner RR (2003) Applying ecological criteria to marine reserve design: a case study from the California Channel Islands. Ecological Applications 13:S170-S184

Albritton DL, Filho M (2001) Technical summary. In: Houghton JT, Ding Y, Griggs DJ, Noguer M, van der Linden PJ, Dai X, Maskell K, Johnson CA (eds) Climate change 2001: the scientific basis. Cambridge University Press, Cambridge, pp 21-83

Allison GW, Lubchenco J, Carr MH (1998) Marine reserves are necessary but not sufficient for marine conservation. Ecological Applications 8:S79-S92

Allison GW, Gaines SD, Lubchenco J, Possingham HP (2003) Ensuring persistence of marine reserves: catastrophes require adopting an insurance factor. Ecological Applications 13:S8-S24

Aronson RB, Precht WF (2006) Conservation, precaution, and Caribbean reefs. Coral Reefs 25:441-450

Baker AC, Glynn PW, Riegl B (2008) Climate change and coral reef bleaching: An ecological assessment of long-term impacts, recovery trends and future outlook. Estuarine, Coastal and Shelf Science 80:435-471

Bakun A (1990) Global climate change and intensification of coastal ocean upwelling. Science 247:198-201

Baldwin A, Egnotovich M, Ford M, Platt W (2001) Regeneration in fringe mangrove forests damaged by Hurricane Andrew. Plant Ecology 157:151-164

Ballantine B (1997) Design principles for systems of 'no-take' marine reserves. In: Presented at a workshop on the design and monitoring of marine reserves, Fisheries Centre, University of British Columbia, Vancouver, $20 \mathrm{pp}$

Baltz DM, Moyle PB (1993) Invasion resistance to introduced species by a native assemblage of California stream fishes. Ecological Applications 3:246-255

Barry JP, Baxter CH, Sagarin RD, Gilman SE (1995) Climate-related, long-term faunal changes in a California rocky intertidal community. Science 267:672-675

Beger M, Jones GP, Munday PL (2003) Conservation of coral reef biodiversity: a comparison of reserve selection procedures for corals and fishes. Biological Conservation 111:53-62 
Behrens MD, Lafferty KD (2004) Effects of marine reserves and urchin disease on southern Californian rocky reef communities. Marine Ecology Progress Series 279:129-139

Bell RE, Studinger M, Shuman CA, Fahnestock MA, Joughin I (2007) Large subglacial lakes in East Antarctica at the onset of fastflowing ice streams. Nature 445:904-907

Bellwood DR, Hughes TP (2001) Regional-scale assembly rules and biodiversity of coral reefs. Science 292:1532-1534

Bellwood DR, Hughes TP, Folke C, Nystroem M (2004) Confronting the coral reef crisis. Nature 429:827-833

Bellwood DR, Hughes TP, Hoey AS (2006) Sleeping functional group drives coral-reef recovery. Current Biology 16:2434-2439

Berkelmans R, van Oppen MJH (2006) The role of zooxanthellae in the thermal tolerance of corals: a "nugget of hope" for coral reefs in an era of climate change. Proceedings of the Royal Society B: Biological Sciences 273:2305-2312

Bindoff NL, Willebrand J, Artale V, Cazenave A, Gregory J, Gulev S, Hanawa K, Le Quere C, Levitus S, Nojiri Y, Shum CK, Talley LD, Unnikrishnan A (2007) Observations: oceanic climate change and sea level. In: Solomon S, Quin D, Manning M, Chen Z, Marquis M, Averyt KB, Tignor M, Miller HL (eds) Climate change 2007: the physical science basis. Contribution of Working Group I to the fourth assessment report of the Intergovernmental Panel on Climate Change. Cambridge University Press, Cambridge, pp 385-432

Boessenkool KP, Hall IR, Elderfield H, Yashayaev I (2007) North Atlantic climate and deep-ocean flow speed changes during the last 230 years. Geophysical Research Letters 34(L13614):1-6

Bohnsack JA (2000) A comparison of the short-term impacts of notake marine reserves and minimum size limits. Bulletin of Marine Science 66:635-650

Boyett HV, Bourne DG, Willis BL (2007) Elevated temperature and light enhance progression and spread of black band disease on staghorn corals of the Great Barrier. Marine Biology 151:17111720

Breitburg DL, Riedel GF (2005) Multiple stressors in marine systems. In: Norse E, Crowder LB (eds) Marine conservation biology: the science of maintaining the sea's biodiversity. Island Press, Washington, DC, pp 167-182

Bruno JF, Selig ER (2007) Regional decline of coral cover in the Indo-Pacific: Timing, extent and subregional comparisons. PLoS ONE 2(8):e711. doi:10:1371/journal.pone.0000711

Burke L, Maidens J (2004) Reefs at risk in the Caribbean. World Resources Institute, Washington, DC, $84 \mathrm{pp}$

Burke L, Selig E, Spalding M (2002) Reefs at risk in Southeast Asia. World Resources Institute, Washington, DC, $76 \mathrm{pp}$

Burkepile DE, Hay ME (2008) Herbivore species richness and feeding complementarity affect community structure and function on a coral reef. Proceedings of the National Academy of Sciences of the USA 105:16201-16206

Burton GA Jr, Pitt R (2001) Stormwater effects handbook: a toolbox for watershed managers, scientists and engineers. Lewis Publishers, Boca Raton, $911 \mathrm{pp}$

Cabanes C, Cazenave A, Le Provost C (2001) Sea level rise during past 40 years determined from satellite and in situ observations. Science 294:840-842

Caldeira K, Wickett ME (2003) Anthropogenic carbon and ocean pH. Nature 425:365-365

Carlton JT (1996) Biological invasions and cryptogenic species. Ecology 77:1653-1655

Carlton JT (2000) Global change and biological invasions in the oceans. In: Mooney HA, Hobbs RJ (eds) Invasive species in a changing world. Island Press, Washington, DC, pp 31-53

Carpenter SR, Caraco NF, Correll DL, Howarth RW, Sharpley AN, Smith VH (1998) Nonpoint pollution of surface waters with phosphorus and nitrogen. Ecological Applications 8:559-568
Carr MH, Neigel JE, Estes JA, Andelman SJ, Warner RR, Largier JL (2003) Comparing marine and terrestrial ecosystems: implications for the design of coastal marine reserves. Ecological Applications 13:S90-S107

Chen JL, Wilson CR, Tapley BD (2006) Satellite gravity measurements confirm accelerated melting of Greenland ice sheet. Science 313:1958-1960

Cho L (2005) Marine protected areas: a tool for integrated coastal management in Belize. Ocean and Coastal Management 48:932947

Cicin-Sain B, Belfiore S (2005) Linking marine protected areas to integrated coastal and ocean management: a review of theory and practice. Ocean and Coastal Management 48:847-868

Coe JM, Rogers D (1997) Marine debris: sources, impacts, and solutions. Springer, New York, $432 \mathrm{pp}$

Condrey R, Fuller D (1992) The US Gulf shrimp fishery. In: Glantz MF (ed) Climate variability, climate change, and fisheries. Cambridge University Press, Cambridge, pp 89-119

Cowen RK, Paris CB, Olson DB, Fortuna JL (2003) The role of long distance dispersal versus local retention in replenishing marine populations. Gulf and Caribbean Research Supplement 14:129_ 137

Cowen RK, Paris CB, Srinivasan A (2006) Scaling of connectivity in marine populations. Science 311:522-527

Crowder LB, Lyman SJ, Figueira WF, Priddy J (2000) Source-sink population dynamics and the problem of siting marine reserves. Bulletin of Marine Science 66:799-820

Crowder LB, Osherenko G, Young OR, Airamé S, Norse EA, Baron N, Day JC, Douvere F, Ehler CN, Halpern BS, Langdon SJ, McLeod KL, Ogden JC, Peach RE, Rosenberg AA, Wilson JA (2006) Resolving mismatches in U.S. ocean governance. Science 313:617-618

Curry R, Mauritzen C (2005) Dilution of the northern Atlantic current in recent decades. Science 308:1772-1774

Curry R, Dickson B, Yashayaev I (2003) A change in the freshwater balance in the Atlantic Ocean over the past four decades. Nature 426:826-829

Davis GE, Loope LL, Roman CT, Smith G, Tilmant JT (1994) Assessment of Hurricane Andrew impacts on natural and archeological resources of Big Cypress National Preserve, Biscayne National Park, and Everglades National Park. National Park Service, Denver, $158 \mathrm{pp}$

Day J, Fernandes L, Lewis A, De'ath G, Slegers S, Barnett B, Kerrigan B, Breen D, Innes J, Oliver J, Ward T, Lowe D (2002) The Representative Areas Program for protecting biodiversity in the Great Barrier Reef World Heritage Area. In: Proceedings of the 9 th international coral reef symposium, vol 2. pp 687-696

Dayton PK, Thrush S, Coleman FC (2002) Ecological effects of fishing in marine ecosystems of the United States. Pew Oceans Commission, Arlington, $45 \mathrm{pp}$

Dickson B, Yashayaev I, Meincke J, Turrell B, Dye S, Holfort J (2002) Rapid freshening of the deep North Atlantic Ocean over the past four decades. Nature 416:832-837

Done T (2001) Scientific principles for establishing MPAs to alleviate coral bleaching and promote recovery. In: Salm RV, Coles SL (eds) Coral bleaching and marine protected areas, proceedings of the workshop on mitigating coral bleaching impact through MPA sesign, Asia Pacific Coastal Marine Program Report \#0102, The Nature Conservancy, Honolulu, HI, pp 60-66

Done T, Jones R (2006) Tropical coastal ecosystems and climate change prediction: global and local risks. In: Phinney JT, HoeghGuldberg O, Kleypas J, Skirving W, Strong A (eds) Coral reefs and climate change: science and management. American Geophysical Union, Washington, DC, pp 5-32 
Done TJ, Reichelt RE (1998) Integrated coastal zone and fisheries ecosystem management: generic goals and performance indices. Ecological Applications 8:S110-S118

Donner SD, Skirving WJ, Little CM, Oppenheimer M, HoeghGuldberg O (2005) Global assessment of coral bleaching and required rates of adaptation under climate change. Global Change Biology 11:2251-2265

Donner SD, Knutson TR, Oppenheimer M (2007) Model-based assessment of the role of human-induced climate change in the 2005 Caribbean coral bleaching event. Proceedings of the National Academy of Sciences of the USA 104:5483-5488

Douglas AE (2003) Coral bleaching-how and why? Marine Pollution Bulletin 46:385-392

Dulvy NK, Sadovy Y, Reynolds JD (2003) Extinction vulnerability in marine populations. Fish and Fisheries 4:25-64

Edge SE, Morgan MB, Gleason DF, Snell TW (2005) Development of a coral cDNA array to examine gene expression profiles in Montastraea faveolata exposed to environmental stress. Marine Pollution Bulletin 51:507-523

Edge SE, Morgan MB, Snell TW (2008) Temporal analysis of gene expression in a field population of the scleractinian coral Montastraea faveolata. Journal of Experimental Marine Biology and Ecology 355:114-124

Edinger EN, Jompa J, Limmon GV, Widjatmoko W, Risk MJ (1998) Reef degradation and coral biodiversity in Indonesia: effects of land-based pollution, destructive fishing practices and changes over time. Marine Pollution Bulletin 36:617-630

Engel J, Kvitek R (1998) Effects of otter trawling on a benthic community in Monterey Bay National Marine Sanctuary. Conservation Biology 12:1204-1214

Engie K, Klinger T (2007) Modeling passive dispersal through a large estuarine system to evaluate marine reserve network connections. Estuaries and Coasts 30:201-213

Estes JA (2005) Carnivory and trophic connectivity in kelp forests. In: Ray JC, Redford KH, Steneck RS, Berger J (eds) Large carnivores and the conservation of biodiversity. Island Press, Washington, DC, pp 61-81

Fabricius KE, De'ath G (2004) Identifying ecological change and its causes: a case study on coral reefs. Ecological Applications 14:1448-1465

Feely RA, Sabine CL, Lee K, Berelson W, Kleypas J, Fabry VJ, Millero FJ (2004) Impact of anthropogenic $\mathrm{CO}_{2}$ on the $\mathrm{CaCO}_{3}$ system in the oceans. Science 305:362-366

Fernandes L, Day J, Lewis A, Slegers S, Kerrigan B, Breen D, Cameron D, Jago B, Hall J, Lowe D, Tanzer J, Chadwick V, Thompson L, Gorman K, Simmons M, Barnett B, Sampson K, De' ath G, Mapstone B, Marsh H, Possingham H, Ball I, Ward T, Dobbs K, Aumend J, Slater D, Stapleton K (2005) Establishing representative no-take areas in the Great Barrier Reef: largescale implementation of theory on marine protected areas. Conservation Biology 19:1733-1744

Fields PA, Graham JB, Rosenblatt RH, Somero GN (1993) Effects of expected global climate change on marine faunas. Trends in Ecology \& Evolution 8:361-367

Fitt WK, Brown BE, Warner ME, Dunne RP (2001) Coral bleaching: interpretation of thermal tolerance limits and thermal thresholds in tropical corals. Coral Reefs 20:51-65

Frank KT, Petrie B, Choi JS, Leggett WC (2005) Trophic cascades in a formerly cod-dominated ecosystem. Science 308:16211623

Freshwater DW, Hines A, Parham S, Wilbur A, Sabaoun M, Woodhead J, Akins L, Purdy B, Whitfield PE, Paris CB (2009) Mitochondrial control region sequence analyses indicate dispersal from the US East Coast as the source of the invasive IndoPacific lionfish Pterois volitans in the Bahamas. Marine Biology 156:1213-1221
Friedlander A, Nowlis JS, Sanchez JA, Appeldoorn R, Usseglio P, Mccormick C, Bejarano S, Mitchell-Chui A (2003) Designing effective marine protected areas in Seaflower Biosphere Reserve, Colombia, based on biological and sociological information. Conservation Biology 17:1769-1784

Galbraith H, Jones R, Park R, Clough J, Herrod-Julius S, Harrington B, Page G (2002) Global climate change and sea level rise: potential losses of intertidal habitat for shorebirds. Waterbirds 25:173-183

Game ET, Watts ME, Wooldridge S, Possingham HP (2008) Planning for persistence in marine reserves: a question of catastrophic importance. Ecological Applications 18:670-680

Gardner TA, Cote IM, Gill JA, Grant A, Watkinson AR (2003) Longterm region-wide declines in Caribbean corals. Science 301:958 960

Gardner TA, Cote IM, Gill JA, Grant A, Watkinson AR (2005) Hurricanes and Caribbean coral reefs: impacts, recovery patterns, and role in long-term decline. Ecology 86:174-184

Gerber LR, Heppell SS (2004) The use of demographic sensitivity analysis in marine species conservation planning. Biological Conservation 120:121-128

Graham NAJ, Evans RD, Russ GR (2003) The effects of marine reserve protection on the trophic relationships of reef fishes on the Great Barrier Reef. Environmental Conservation 30:200-208

Greene CH, Pershing AJ (2007) Climate drives sea change. Science 315:1084-1085

Grigg RW, Dollar SJ, Huppert A, Causey BD, Andrews K, Kruczynski WL, Precht WF, Miller SL, Aronson RB, Bruno JF (2005) Reassessing U.S. coral reefs. Science 308:1740-1742

Gunderson LH (2000) Ecological resilience-in theory and application. Annual Review of Ecology and Systematics 31:425-439

Hallock P (2005) Global change and modern coral reefs: New opportunities to understand shallow-water carbonate depositional processes. Sedimentary Geology 175:19-33

Halpern BS, Regan HM, Possingham HP, McCarthy MA (2006) Accounting for uncertainty in marine reserve design. Ecological Letters 9:2-11

Hansen L, Biringer JL, Hoffman JR (eds) (2003) Buying time: a user's manual for building resistance and resilience to climate change in natural systems. WWF Climate Change Program, Berlin, $246 \mathrm{pp}$

Hare JA, Whitfield PE (2003) An integrated assessment of the introduction of lionfish (Pterois volitans/miles complex) to the western Atlantic Ocean. NOAA Technical Memorandum NOS NCCOS 2, $21 \mathrm{pp}$

Harley CDG, Hughes R, Hultgren KM, Miner BG, Sorte CJB, Thornber CS, Rodriguez LF, Tomanek L, Williams SL (2006) The impacts of climate change in coastal marine systems. Ecology Letters 9:228-241

Harvell CD, Kim K, Burkholder JM, Colwell RR, Epstein PR, Grimes DJ, Hofmann EE, Lipp EK, Oterhaus A, Overstreet RM (1999) Emerging marine diseases-climate links and anthropogenic factors. Science 285:1505-1510

Harvell D, Kim K, Quirolo C, Weir J, Smith G (2001) Coral bleaching and disease: contributors to 1998 mass mortality in Briareum asbestinum (Octocorallia, Gorgonacea). Hydrobiologia 460:97-104

Harvell CD, Mitchell CE, Ward JR, Altizer S, Dobson AP, Ostfeld RS, Samuel MD (2002) Climate warming and disease risks for terrestrial and marine biota. Science 296:2158-2162

Hastings A, Botsford LW (2003) Comparing designs of marine reserves for fisheries and for biodiversity. Ecological Applications 13:S65-S70

Hiddink JG, Jennings S, Kaiser MJ (2006) Indicators of the ecological impact of bottom-trawl disturbance on seabed communities. Ecosystems 9:1190-1199 
Hixon MA, Tissot BN (2007) Comparison of trawled vs untrawled mud seafloor assemblages of fishes and macroinvertebrates at Coquille Bank, Oregon. Journal of Experimental Marine Biology and Ecology 344:23-24

Hockey PAR, Branch GM (1994) Conserving marine biodiversity on the African coast: implications of a terrestrial perspective. Aquatic Conservation Marine and Freshwater Ecosystems $4: 345-362$

Hoegh-Guldberg O (1999) Climate change, coral bleaching and the future of the world's coral reefs. Marine \& Freshwater Research 50:839-866

Hoegh-Guldberg O, Mumby PJ, Hooten AJ, Steneck RS, Greenfield P, Gomez E, Harvell CD, Sale PF, Edwards AJ, Caldeira K, Knowlton N, Eakin CM, Iglesias-Prieto R, Muthiga N, Bradbury RH, Dubi A, Hatziolos M (2007a) Coral reefs under rapid climate change and ocean acidification. Science 318:1737-1742

Hoegh-Guldberg O, Anthony K, Berkelmans R, Dove S, Fabricius K, Lough J, Marshall PA, van Oppen MJH, Negri A, Willis B (2007b) Vulnerability of reef-building corals on the Great Barrier Reef to climate change. In: Johnson JE, Marshall PA (eds) Climate change and the Great Barrier Reef. Great Barrier Reef Marine Park Authority \& Australian Greenhouse Office, Australia, pp 271-307

Hughes TP, Baird AH, Bellwood DR, Card M, Connolly SR, Folke C, Grosberg R, Hoegh-Guldberg O, Jackson JBC, Kleypas J, Lough JM, Marshall P, Nystrom M, Palumbi SR, Pandolfi JM, Rosen N, Roughgarden J (2003) Climate change, human impacts, and the resilience of coral reefs. Science 301:929-933

Hughes TP, Bellwood DR, Folke C, Steneck RS, Wilson J (2005) New paradigms for supporting the resilience of marine ecosystems. Trends in Ecology \& Evolution 20:380-386

Hyrenbach KD, Forney KA, Dayton PK (2000) Marine protected areas and ocean basin management. Aquatic Conservation: Marine and Freshwater Ecosystems 10:437-458

Intergovernmental Panel on Climate Change (IPCC) (2007a) In: Solomon S, Qin D, Manning M, Chen Z, Marquis M, Averyt KB, Tignor M, Miller HL (eds) Climate change 2007: the physical science basis. Contribution of Working Group I to the fourth assessment report of the Intergovernmental Panel on Climate Change. Cambridge University Press, Cambridge, 996 pp

IPCC (2007b) In: Parry ML, Canziani OF, Palutikof JP, van der Linden PJ, Hanson CE (eds) Climate change 2007: impacts, adaptation and vulnerability. Contribution of Working Group II to the fourth assessment report of the Intergovernmental Panel on Climate Change. Cambridge University Press, Cambridge, $976 \mathrm{pp}$

IPCC (2007c) In: Metz B, Davidson OR, Bosch PR, Dave R, Meyer LA (eds) Climate change 2007: mitigation. Contribution of Working Group III to the fourth assessment report of the Intergovernmental Panel on Climate Change. Cambridge University Press, Cambridge, $852 \mathrm{pp}$

Jackson JBC (2008) Ecological extinction and evolution in the brave new ocean. Proceedings of the National Academy of Sciences of the USA 105:11458-11465

Jackson JBC, Kirby MX, Berger WH, Bjorndal KA, Botsford LW, Bourque BJ, Bradbury RH, Cooke R, Erlandson J, Estes JA, Hughes TP, Kidwell S, Lange CB, Lenihan HS, Pandolfi JM, Peterson CH, Steneck RS, Tegner MJ, Warner RR (2001) Historical overfishing and the recent collapse of coastal ecosystems. Science 293:629-638

Johnson JE, Marshall PA (2007) Climate change and the Great Barrier Reef: a vulnerability assessment. Great Barrier Reef Marine Park Authority and Australian Greenhouse Office, Australia, $818 \mathrm{pp}$

Jones GP, Milicich MJ, Emslie MJ, Lunow C (1999) Self-recruitment in a coral reef fish population. Nature 402:802-804
Jones GP, Planes S, Thorrold SR (2005) Coral reef fish larvae settle close to home. Current Biology 15:1314-1318

Kaiser MJ (2005) Are marine protected areas a red herring or fisheries panacea? Canadian Journal of Fisheries and Aquatic Sciences 62:1194-1199

Kaufman L, Jackson JBC, Sala E, Chisolm P, Gomez ED, Peterson C, Salm RV, Llewellyn G (2004) Restoring and maintaining marine ecosystem function. In: Glover LK, Earle SA (eds) Defying ocean's end. Island Press, Washington, DC, pp 165-181

Keller BD, Airamé S, Causey B, Friedlander A, Gleason DF, GroberDunsmore R, Johnson J, McLeod E, Miller SL, Steneck RS, Woodley C (2008) Marine protected areas. In: Julius SH, West JM (eds), Baron JS, Joyce LA, Kareiva P, Keller BD, Palmer MA, Peterson CH, Scott JM (authors) A preliminary review of adaptation options for climate-sensitive ecosystems and resources. A report by the U.S. Climate Change Science Program and the Subcommittee on Global Change Research. U.S. Environmental Protection Agency, Washington, DC, 95 pp

Khamer M, Bouya D, Ronneau C (2000) Metallic and organic pollutants associated with urban wastewater in the waters and sediments of a Moroccan river. Water Quality Research Journal of Canada 35:147-161

Kim K, Harvell CD (2004) The rise and fall of a six-year coral-fungal epizootic. American Naturalist 164:S52-S63

Kimball ME, Miller JM, Whitfield PE, Hare JA (2004) Thermal tolerance and potential distribution of invasive lionfish (Pterois volitans/miles complex) on the east coast of the United States. Marine Ecology Progress Series 283:269-278

Kinlan BP, Gaines SD (2003) Propagule dispersal in marine and terrestrial environments: a community perspective. Ecology 84:2007-2020

Klein RJT, Nicholls RJ (1999) Assessment of coastal vulnerability to climate change. Ambio 28:182-187

Kleypas JA, Langdon C (2006) Coral reefs and changing seawater chemistry. In: Phinney JT, Hoegh-Guldberg O, Kleypas J, Skirving WJ, Strong A (eds) Coral reefs and climate change: science and management. American Geophysical Union, Washington, DC, pp 73-110

Kleypas JA, Buddemeier RW, Archer D, Gattuso JP, Langdon C, Opdyke BN (1999) Geochemical consequences of increased atmospheric carbon dioxide on coral reefs. Science 284:118-120

Kleypas JA, Feely RA, Fabry VJ, Langdon C, Sabine CL, Robbins LL (2006) Impacts of ocean acidification on coral reefs and other marine calcifiers: a guide to future research. Report of a workshop held 18-20 April 2005, St. Petersburg, FL, sponsored by NSF, NOAA, and the U.S. Geological Survey, $88 \mathrm{pp}$

Langdon C, Atkinson MJ (2005) Effect of elevated $\mathrm{pCO}_{2}$ on photosynthesis and calcification of corals and interactions with seasonal change in temperature/irradiance and nutrient enrichment. Journal of Geophysical Research 110:CC09S07. doi: 10.1029/2004JC002576

Law R, Stokes K (2005) Evolutionary impacts of fishing on target populations. In: Norse E, Crowder LB (eds) Marine conservation biology: the science of maintaining the sea's biodiversity. Island Press, Washington, DC, pp 232-246

Ledlie MH, Graham NAJ, Bythell JC, Wilson SK, Jennings S, Polunin NVC, Hardcastle J (2007) Phase shifts and the role of herbivory in the resilience of coral reefs. Coral Reefs 26:641653

Lesser MP, Bythell JC, Gates RD, Johnstone RW, Hoegh-Guldberg O (2007) Are infectious diseases really killing corals? Alternative interpretations of the experimental and ecological data. Journal of Experimental Marine Biology and Ecology 346:36-44

Levin SA, Lubchenco J (2008) Resilience, robustness, and marine ecosystem-based management. BioScience 58:27-32 
Lirman D, Fong P (2007) Is proximity to land-based sources of coral stressors an appropriate measure of risk to coral reefs? An example from the Florida Reef tract. Marine Pollution Bulletin 54:779-791

Lotze HK, Lenihan HS, Bourque BJ, Bradbury RH, Cooke RG, Kay MC, Kidwell SM, Kirby MX, Peterson CH, Jackson JBC (2006) Depletion, degradation, and recovery potential of estuaries and coastal seas. Science 312:1806-1809

Lovelace JK, McPherson BF (1998) Effects of Hurricane Andrew on wetlands in southern Florida and Louisiana. National Water Summary on Wetland Resources, United States Geological Survey Water Supply Paper \#2425. http://water.usgs.gov/ nwsum/WSP2425/andrew.html, Accessed 5 December 2008

Mann KH, Lazier JRN (2006) Dynamics of marine ecosystems, 3rd edn. Blackwell Publishing, Malden, 496 pp

Mantua NJ, Hare SR, Zhang Y, Wallace JM, Francis RC (1997) A Pacific interdecadal climate oscillation with impacts on salmon production. Bulletin of the American Meteorological Society 78:1069-1079

Marchetti MP, Moyle PB, Levine R (2004) Invasive species profiling? Exploring the characteristics of non-native fishes across invasion stages in California. Freshwater Biology 49:646-661

Marshall P, Schuttenberg H (2006a) A reef manager's guide to coral bleaching. Great Barrier Reef Marine Park Authority, Townsville, $178 \mathrm{pp}$

Marshall P, Schuttenberg H (2006b) Adapting coral reef management in the face of climate change. In: Phinney JT, Hoegh-Guldberg O, Kleypas J, Skirving WJ, Strong A (eds) Coral reefs and climate change: science and management. American Geophysical Union, Washington, DC, pp 223-241

McCarty JP (2001) Ecological consequences of recent climate change. Conservation Biology 15:320-331

McClanahan TR, Polunin NVC, Done TJ (2002) Resilience of coral reefs. In: Gunderson LH, Pritchard L Jr (eds) Resilience and behaviour of large-scale ecosystems. Island Press, Washington, DC, pp 111-163

McCoy ED, Mushinsky HR, Johnson D, Meshaka WE Jr (1996) Mangrove damage caused by Hurricane Andrew on the southwestern coast of Florida. Bulletin of Marine Science $59: 1-8$

McGowan JA, Cayan DR, Dorman LM, Butler A (1998) Climateocean variability and ecosystem response in the Northeast Pacific. Science 281:210-217

McGregor HV, Dima M, Fischer HW, Mulitza S (2007) Rapid 20thcentury increase in coastal upwelling off northwest Africa. Science 315:637-639

McLeod E, Salm RV (2006) Managing mangroves for resilience to climate change. The World Conservation Union, Gland, $66 \mathrm{pp}$

McLeod E, Salm RV, Anthony K, Causey B, Conklin E, Cros A, Feely R, Guinotte J, Hofmann G, Hoffman J, Jokiel P, Kleypas J, Marshall P, Veron C (2008a) The Honolulu declaration on ocean acidification and reef management. The Nature Conservancy, USA, and IUCN, Gland, Switzerland, $33 \mathrm{pp}$

McLeod E, Salm R, Green A, Almany J (2008b) Designing marine protected area networks to address the impacts of climate change. Frontiers in Ecology and the Environment. doi: 10.1890/070211 (published online)

McManus JW (1997) Tropical marine fisheries and the future of coral reefs: a brief review with emphasis on Southeast Asia. Coral Reefs 16:S121-S127

McNaughton SJ (1977) Diversity and stability of ecological communities: a comment on the role of empiricism in ecology. American Naturalist 111:515-525

McNeil BI, Matear RJ, Barnes DJ (2004) Coral reef calcification and climate change: the effect of ocean warming. Geophysical Research Letters 31(L22309):1-4
McPhaden MJ, Zhang D (2002) Slowdown of the meridional overturning circulation in the upper Pacific Ocean. Nature 415:603-608

Michaelidis B, Ouzounis BC, Paleras A, Portner HO (2005) Effects of long-term moderate hypercapnia on acid-base balance and growth rate in marine mussels Mytilus galloprovinciallis. Marine Ecology Progress Series 293:109-118

Micheli F, Halpern BS, Botsford LW, Warner RR (2004) Trajectories and correlates of community change in no-take marine reserves. Ecological Applications 14:1709-1723

Mills LS, Soulé ME, Doak DF (1993) The keystone-species concept in ecology and conservation. BioScience 43:219-224

Moore MV, Pace ML, Mather JR, Murdoch PS, Howarth RW, Folt CL, Chen CY, Hemond HF, Flebbe PA, Driscoll CT (1997) Potential effects of climate change on freshwater ecosystems of the New England/Mid-Atlantic region. Hydrological Processes 11:925-947

Mora C, Andréfouët S, Costello MJ, Kranenburg C, Rollo A, Veron J, Gaston KJ, Myers RA (2006) Coral reefs and the global network of marine protected areas. Science 312:1750-1751

Mosquera I, Cote IM, Jennings S, Reynolds JD (2000) Conservation benefits of marine reserves for fish populations. Animal Conservation 3:321-332

Moyle PB (1986) Fish introductions into North America: patterns and ecological impact. In: Mooney HA, Drake JA (eds) Ecology of biological invasions of North America and Hawaii. Springer, New York, pp 27-43

Mumby PJ, Edwards AJ, Arias-Gonzalez JE, Lindeman KC, Blackwell PG, Gall A, Gorczynska MI, Harborne AR, Pescod CL, Renken H, Wabnitz CCC, Llewellyn G (2004) Mangroves enhance the biomass of coral reef fish communities in the Caribbean. Nature 427:533-536

Mumby PJ, Dahlgren CP, Harborne AR, Kappel CV, Micheli F, Brumbaugh DR, Holmes KE, Mendes JM, Broad K, Sanchirico JN (2006) Fishing, trophic cascades, and the process of grazing on coral reefs. Science 311:98-101

Mumby PJ, Harborne AR, Williams J, Kappel CV, Brumbaugh DR, Micheli F, Holmes KE, Dahlgren CP, Paris CB, Blackwell PG (2007) Trophic cascade facilitates coral recruitment in a marine reserve. Proceedings of the National Academy of Sciences of the USA 104:8362-8367

Munn CB (2006) Viruses as pathogens of marine organisms-from bacteria to whales. Journal of the Marine Biological Association of the UK 86:453-467

Murawski SA (1993) Climate change and marine fish distributions: forecasting from historical analogy. Transactions of the American Fisheries Society 122:647-658

Mydlarz LD, Jones LE, Harvell CD (2006) Innate immunity, environmental drivers, and disease ecology of marine and freshwater invertebrates. Annual Review of Ecology, Evolution and Systematics 37:251-288

Nagelkerken I, Dorenbosch M, Verberk W, de la Moriniere EC, van der Velde G (2000) Importance of shallow-water biotopes of a Caribbean bay for juvenile coral reef fishes: patterns in biotope association, community structure and spatial distribution. Marine Ecology Progress Series 202:175-192

National Marine Fisheries Service (NMFS) (2005) 2005 report on the status of U.S. marine fish stocks. National Marine Fisheries Service, Silver Spring, $20 \mathrm{pp}$

National Research Council (NRC) (1999) Sustaining marine fisheries. National Academy Press, Washington, DC, $164 \mathrm{pp}$

NRC (2001) Marine protected areas: tools for sustaining ocean ecosystems. National Academy Press, Washington, DC, 272 pp

Nicholls RJ, Leatherman SP (1996) Adapting to sea-level rise: relative sea-level trends to 2100 for the United States. Coastal Management 24:301-324 
Norse EA (ed) (1993) Global marine biological diversity: a strategy for building conservation into decision making. Island Press, Washington, DC, $383 \mathrm{pp}$

Nyström M, Folke C, Moberg F (2000) Coral reef disturbance and resilience in a human-dominated environment. Trends in Ecology \& Evolution 15:413-417

O'Connor MI, Bruno JF, Gaines SD, Halpern BS, Lester SE, Kinlan BP, Weiss JM (2007) Temperature control of larval dispersal and the implications for marine ecology, evolution, and conservation. Proceedings of the National Academy of Sciences of the USA 104:1266-1271

Ogden JC, Gladfelter EH (1983) Coral reefs, seagrass beds and mangroves: their interaction in the coastal zones of the Caribbean. UNESCO Reports in Marine Science 23:133

Orr JC, Fabry VJ, Aumont O, Bopp L, Doney SC, Feely RA, Gnanadesikan A, Gruber N, Ishida A, Joos F, Key RM, Lindsay K, Maier-Reimer E, Matear R, Monfray P, Mouchet A, Najjar RG, Plattner GK, Rodgers KB, Sabine CL, Sarmiento JL, Schlitzer R, Slater RD, Totterdell IJ, Weirig MF, Yamanaka Y, Yool A (2005) Anthropogenic ocean acidification over the twenty-first century and its impact on calcifying organisms. Nature 437:681-686

Orth RJ, Carruthers TJB, Dennison WC, Duarte CM, Fourqurean JW, Heck KL Jr, Hughes AR, Kendrick GA, Kenworthy WJ, Olyarnik S, Short FT, Waycott M, Williams SL (2006) A global crisis for seagrass ecosystems. BioScience 56:987-996

Palumbi SR (2002) Marine reserves: a tool for ecosystem management and conservation. Pew Oceans Commission, Arlington, $45 \mathrm{pp}$

Palumbi SR (2003) Population genetics, demographic connectivity, and the design of marine reserves. Ecological Applications 13:S146-S158

Palumbi SR (2004) Marine reserves and ocean neighborhoods: the spatial scale of marine populations and their management. Annual Review of Environment and Resources 29:31-68

Palumbi SR, Grabowsky G, Duda T, Geyer L, Tachino N (1997) Speciation and population genetic structure in tropical Pacific sea urchins. Evolution 51:1506-1517

Palumbi SR, McLeod KL, Grünbaum D (2008) Ecosystems in action: lessons from marine ecology about recovery, resistance, and reversibility. BioScience 58:33-42

Palumbi SR, Sandifer PA, Allan JD, Beck MW, Fautin DG, Fogarty MJ, Halpern BS, Incze LS, Leong J, Norse E, Stachowicz JJ, Wall DH (2009) Managing for ocean biodiversity to sustain marine ecosystem services. Frontiers in Ecology and the Environment 7:204-211

Pandolfi JM, Bradbury RH, Sala E, Hughes TP, Bjorndal KA, Cooke RG, McArdle D, McClenachan L, Newman MJH, Paredes G, Warner RR, Jackson JBC (2003) Global trajectories of the longterm decline of coral reef ecosystems. Science 301:955-958

Pandolfi JM, Jackson JBC, Baron N, Bradbury RH, Guzman HM, Hughes TP, Kappel CV, Micheli F, Ogden JC, Possingham HP, Sala E (2005) Are U.S. coral reefs on the slippery slope to slime? Science 307:1725-1726

Pane EF, Barry JP (2007) Extracellular acid-base regulation during short-term hypercapnia is effective in a shallow-water crab, but ineffective in a deep-sea crab. Marine Ecology Progress Series 334:1-9

Paris CB, Cowen RK (2004) Direct evidence of a biophysical retention mechanism for coral reef fish larvae. Limnology and Oceanography 49:1964-1979

Pauly D, Christensen V, Dalsgaard J, Froese R, Torres F Jr (1998) Fishing down marine food webs. Science 279:860-863

Pauly D, Alder J, Bennett E, Christensen V, Tyedmers P, Watson R (2003) The future for fisheries. Science 302:1359-1361

Perry AL, Low PJ, Ellis JR, Reynolds JD (2005) Climate change and distribution shifts in marine fishes. Science 308:1912-1915
Peterson BJ, McClelland J, Curry R, Holmes RM, Walsh JE, Aagaard K (2006) Trajectory shifts in the Arctic and subarctic freshwater cycle. Science 313:1061-1066

Pew Oceans Commission (POC) (2003) America's living oceans: charting a course for sea change-a report to the nation. Pew Oceans Commission, Arlington, $144 \mathrm{pp}$

Philip S, van Oldenborgh GJ (2006) Shifts in ENSO coupling processes under global warming. Geophysical Research Letters 33(L11704):1-5

Porter JW, Dustan P, Jaap WC, Patterson KL, Kosmynin V, Meier OW, Patterson ME, Parsons M (2001) Patterns of spread of coral disease in the Florida Keys. Hydrobiologia 460:1-24

Porter JW, Kosmynin V, Patterson KL, Porter KG, Jaap WC, Wheaton JL, Hackett K, Lybolt M, Tsokos CP, Yanev G, Marcinek GM, Dotten J, Eaken D, Patterson M, Meier OW, Brill M, Dustan P (2002) Detection of coral reef change by the Florida Keys Coral Reef Monitoring Project. In: Porter JW, Porter KG (eds) The Everglades, Florida Bay, and coral reefs of the Florida Keys: an ecosystem sourcebook. CRC Press, Boca Raton, pp 749-769

Precht WF, Aronson RB (2004) Climate flickers and range shifts of reef corals. Frontiers in Ecology and the Environment 2:307-314

Rabalais NN, Turner RE, Wiseman WJ Jr (2002) Gulf of Mexico hypoxia, aka "the dead zone". Annual Review of Ecology and Systematics 33:235-263

Reaser JK, Pomerance R, Thomas PO (2000) Coral bleaching and global climate change: scientific findings and policy recommendations. Conservation Biology 14:1500-1511

Rignot E, Kanagaratnam P (2006) Changes in the velocity structure of the Greenland icesheet. Science 311:986-990

Roberts CM (1996) Settlement and beyond: population regulation and community structure of reef fishes. In: Polunin NVC, Roberts CM (eds) Reef fisheries. Chapman \& Hall, London, pp 85-112

Roberts CM (1997) Connectivity and management of Caribbean coral reefs. Science 278:1454-1457

Roberts CM (2005) Marine protected areas and biodiversity conservation. In: Norse E, Crowder LB (eds) Marine conservation biology: the science of maintaining the sea's biodiversity. Island Press, Washington, DC, pp 265-279

Roberts CM (2007) The unnatural history of the sea. Island Press, Washington, DC, $435 \mathrm{pp}$

Roberts CM, Bohnsack JA, Gell F, Hawkins JP, Goodridge R (2001) Effects of marine reserves on adjacent fisheries. Science 294:1920-1923

Roberts CM, Andelman S, Branch G, Bustamante RH, Castilla JC, Dugan J, Halpern BS, Lafferty KD, Leslie H, Lubchenco J, McArdle D, Possingham HP, Ruckelshaus M, Warner RR (2003a) Ecological criteria for evaluating candidate sites for marine reserves. Ecological Applications 13:S199-S214

Roberts CM, Branch G, Bustamante RH, Castilla JC, Dugan J, Halpern BS, Lafferty KD, Leslie H, Lubchenco J, McArdle D, Ruckelshaus M, Warner RR (2003b) Application of ecological criteria in selecting marine reserves and developing reserve networks. Ecological Applications 13:S215-S228

Roberts JM, Wheeler AJ, Freiwald A (2006) Reefs of the deep: the biology and geology of cold-water coral ecosystems. Science 312:543-547

Robertson DR, Choat JH, Posada JM, Pitt J, Ackerman JL (2005) Ocean surgeonfish Acanthurus bahianus. II. Fishing effects on longevity, size and abundance? Marine Ecology Progress Series 295:245-256

Roessig JM, Woodley CM, Cech JJ, Hansen LJ (2004) Effects of global climate change on marine and estuarine fishes and fisheries. Reviews in Fish Biology and Fisheries 14:251-275

Rosenberg AA, McLeod KL (2005) Implementing ecosystem-based approaches to management for the conservation of ecosystem services. Marine Ecology Progress Series 300:241-296 
Ruckelshaus M, Klinger T, Knowlton N, deMaster DP (2008) Marine ecosystem-based management in practice: scientific and governance challenges. BioScience 58:53-63

Ruiz GM, Fofonoff PW, Carlton JT, Wonham MJ, Hines AH (2000) Invasion of coastal marine communities in North America: apparent patterns, processes, and biases. Annual Review of Ecology and Systematics 31:481-531

Sabine CL, Feely RA, Gruber N, Key RM, Lee K, Bullister JL, Wanninkhof R, Wong CS, Wallace DWR, Tilbrook B, Millero FJ, Peng T-H, Kozyr A, Ono T, Rios AF (2004) The oceanic sink for anthropogenic $\mathrm{CO}_{2}$. Science 305:367-371

Sadovy Y (2006) Protecting the spawning and nursery habitats of fish: the use of MPAs to safeguard critical life-history stages for marine life. MPA News: International News and Analysis on Marine Protected Areas 8:1-3

Sale PF, Cowen RK, Danilowicz BS, Jones GP, Kritzer JP, Lindeman KC, Planes S, Polunin NVC, Russ GR, Sadovy YJ, Steneck RS (2005) Critical science gaps impede use of no-take fishery reserves. Trends in Ecology \& Evolution 20:74-80

Salm RV, Coles SL (eds) (2001) Coral bleaching and marine protected areas. In: Proceedings of the Workshop on Mitigating Coral Bleaching Impact Through MPA Design, Asia Pacific Coastal Marine Program Report \# 0102, The Nature Conservancy, Honolulu, HI, $118 \mathrm{pp}$

Salm R, Clark J, Siirila E (2000) Marine and coastal protected areas: a guide for planners and managers. Report Number 3, International Union for Conservation of Nature and Natural Resources, Washington, DC, $387 \mathrm{pp}$

Salm RV, Smith SE, Llewellyn G (2001) Mitigating the impact of coral bleaching through marine protected area design. In: Schuttenberg HZ (ed), Coral bleaching: causes, consequences, and response. Coastal Management Report 2230, Coastal Resources Center, University of Rhode Island, Narragansett, RI, pp 81-89

Salm RV, Done T, McLeod E (2006) Marine protected area planning in a changing climate. In: Phinney JT, Hoegh-Guldberg O, Kleypas J, Skirving WJ, Strong A (eds) Coral reefs and climate change: science and management. American Geophysical Union, Washington, DC, pp 207-221

Scavia D, Field JC, Boesch DF, Buddemeier RW, Burkett V, Cayan DR, Fogarty M, Harwell MA, Howarth RW, Mason C, Reed DJ, Royer TC, Sallenger AH, Titus JG (2002) Climate change impacts on U.S. coastal and marine ecosystems. Estuaries 25:149-164

Shanks AL, Grantham BA, Carr MH (2003) Propagule dispersal distance and the size and spacing of marine reserves. Ecological Applications 13:S159-S169

Shepherd A, Wingham D (2007) Recent sea-level contributions of the Antarctic and Greenland ice sheets. Science 315:1529-1532

Shirayama Y, Thornton H (2005) Effect of increased atmospheric $\mathrm{CO}_{2}$ on shallow water marine benthos. Journal of Geophysical Research 110(C09S08):1-7

Smith SV, Buddemeier RW (1992) Global change and coral reef ecosystems. Annual Review of Ecology and Systematics 23:89118

Snyder DB, Burgess GH (2007) The Indo-Pacific red lionfish, Pterois volitans (Pisces: Scorpaenidae), new to Bahamian ichthyofauna. Coral Reefs 26:175

Snyder MA, Sloan LC, Diffenbaugh NS, Bell JL (2003) Future climate change and upwelling in the California current. Geophysical Research Letters 30(1823):1-4

Sobel JA, Dahlgren C (2004) Marine reserves: a guide to science, design, and use. Island Press, Washington, DC, $383 \mathrm{pp}$

Sotka EE, Wares JP, Barth JA, Grosberg RK, Palumbi SR (2004) Strong genetic clines and geographical variation in gene flow in the rocky intertidal barnacle Balanus glandula. Molecular Ecology 13:2143-2156

Soto CG (2002) The potential impacts of global climate change on marine protected areas. Reviews in Fish Biology and Fisheries 11:181-195

Sousa WP (1984) The role of disturbance in natural communities. Annual Review of Ecology and Systematics 15:353-391

Stachowicz JJ, Terwin JR, Whitlatch RB, Osman RW (2002) Linking climate change and biological invasions: ocean warming facilitates nonindigenous species invasions. Proceedings of the National Academy of Sciences of the USA 99:15497-15500

Steneck RS (1997) Fisheries-induced biological changes to the structure and function of the Gulf of Maine ecosystem. In: Wallace G, Braasch E (eds) Proceedings of the Gulf of Maine Ecosystem Dynamics Scientific Symposium and Workshop, Regional Association for Research in the Gulf of Maine, RARGOM Report 97-1, pp 151-165

Steneck RS (2006) Staying connected in a turbulent world. Science 311:480-481

Steneck RS, Sala E (2005) Large marine carnivores: trophic cascades and top-down controls in coastal ecosystems past and present. In: Ray JC, Redford KH, Steneck RS, Berger J (eds) Large carnivores and the conservation of biodiversity. Island Press, Washington, DC, pp 110-137

Steneck RS, Graham MH, Bourque BJ, Corbett D, Erlandson JM, Estes JA, Tegner MJ (2002) Kelp forest ecosystems: biodiversity, stability, resilience and future. Environmental Conservation 29:436-459

Steneck RS, Vavrinec J, Leland AV (2004) Accelerating trophic level dysfunction in kelp forest ecosystems of the western North Atlantic. Ecosystems 7:323-331

Stewart RR, Noyce T, Possingham HP (2003) Opportunity cost of ad hoc marine reserve design decisions: an example from South Australia. Marine Ecology Progress Series 253:25-38

Swearer SE, Caselle JE, Lea DW, Warner RR (1999) Larval retention and recruitment in an island population of a coral-reef fish. Nature 402:799-802

The Royal Society (TRS) (2005) Ocean acidification due to increasing atmospheric carbon dioxide. The Royal Society, London, 60 $\mathrm{pp}$

Thorrold SR, Latkoczy C, Swart PK, Jones CM (2001) Natal homing in a marine fish metapopulation. Science 291:297-299

Thrush SF, Dayton PK (2002) Disturbance to marine benthic habitats by trawling and dredging: implications for marine biodiversity. Annual Review of Ecology and Systematics 33:449-473

Tilmant JT, Curry RW, Jones R, Szmant A, Zieman JC, Flora M, Robblee MB, Smith D, Snow RW, Wanless H (1994) Hurricane Andrew's effects on marine resources: the small underwater impact contrasts sharply with the destruction in mangrove and upland-forest communities. BioScience 44:230-237

US Commission on Ocean Policy (USCOP) (2004) An ocean blueprint for the 21 st century. Final report. U.S. Commission on Ocean Policy, Washington, DC, $522 \mathrm{pp}$

US Department of Commerce (USDOC) (1996) Final management plan/environmental impact statement for the Florida Keys National Marine Sanctuary, vol I. National Oceanic and Atmospheric Administration, Silver Spring, $319 \mathrm{pp}$

Walther GR, Post E, Convey P, Menzel A, Parmesan C, Beebee TJC, Fromentin JM, Hoegh-Guldberg O, Bairlein F (2002) Ecological responses to recent climate change. Nature 416:389-395

Warner RR, Swearer SE, Caselle JE (2000) Larval accumulation and retention: implications for the design of marine reserves and essential fish habitat. Bulletin of Marine Science 66:821-830

Wells S (2006) Assessing the effectiveness of marine protected areas as a tool for improving coral reef management. In: Côté I, 
Reynolds J (eds) Coral reef conservation. Cambridge University Press, Cambridge, pp 314-331

West JM, Salm RV (2003) Resistance and resilience to coral bleaching: implications for coral reef conservation and management. Conservation Biology 17:956-967

Whelan KRT, Miller J, Sanchez O, Patterson M (2007) Impact of the 2005 coral bleaching event on Porites porites and Colpophyllia natans at Tektite Reef, US Virgin Islands. Coral Reefs 26:689693

Whitfield PE, Hare JA, David AW, Harter SL, Muñoz RC, Addison CM (2007) Abundance estimates of the Indo-Pacific lionfish Pterois volitans/miles complex in the western North Atlantic. Biological Invasions 9:53-64

Wilkinson CR (1998) Status of coral reefs of the world: 1998. Australian Institute of Marine Science, Townsville, $184 \mathrm{pp}$

Wilkinson CR (2000) Status of coral reefs of the world: 2000. Australian Institute of Marine Science, Townsville, 363 pp
Wilkinson CR (2002) Status of coral reefs of the world: 2002. Australian Institute of Marine Science, Townsville, 378 pp

Wilkinson CR (2004) Status of coral reefs of the world: 2004, vols 1, 2. Australian Institute of Marine Science, Townsville, $602 \mathrm{pp}$

Wilkinson C, Linden O, Cesar H, Hodgson G, Rubens J, Strong AE (1999) Ecological and socioeconomic impacts of 1998 coral mortality in the Indian Ocean: an ENSO impact and a warning of future change? Ambio 28:188-195

Yates KK, Halley RB (2006) $\mathrm{CO}_{3}^{2-}$ concentration and $\mathrm{pCO}_{2}$ thresholds for calcification and dissolution on the Molokai reef flat, Hawaii. Biogeosciences 3:357-369

Zervas C (2001) Sea level variations of the United States, 1854-1999. Technical Report NOS CO-OPS 36, US Department of Commerce, National Oceanic and Atmospheric Administration, National Ocean Service, Silver Spring, 65 pp 